\title{
MPRA
}

Munich Personal RePEc Archive

The Impacts of Strengthening Regulatory Surveillance on Bank Behavior: A Dynamic Analysis from Incomplete to Complete Enforcement of Capital Regulation in Microprudential Policy

NAKASHIMA, KIYOTAKA and Ogawa, Toshiaki Independent Economist, Musashi University

11 August 2021

Online at https://mpra.ub.uni-muenchen.de/109147/

MPRA Paper No. 109147, posted 11 Aug 2021 15:04 UTC 


\section{The Impacts of Strengthening Regulatory Surveillance on Bank Behavior: A Dynamic Analysis from Incomplete to Complete Enforcement of Capital Regulation in Microprudential Policy *}

\author{
KiYOtaka NAKashima ${ }^{\dagger}$ \\ INDEPENDENT ECONOMIST
}

\author{
TOSHIAKI OGaWA $\ddagger$ \\ Musashi UnIVERSity
}

August, 2021

ABSTRACT. This study examines the impact of strengthening bank capital supervision on bank behavior in the incomplete enforcement of regulations. In a dynamic model of banks facing persistent idiosyncratic shocks, banks accumulate regulatory capital and decrease charter value and lending in the short run, while in the long run, the banking system achieves stability. To test the short-run implications, we utilize the introduction of the prompt corrective action program in Japan as a quasinatural experiment. Using some empirical specifications with bank- and loan-level data, we find empirical evidence consistent with the theoretical predictions.

JEL classification: G00, G21, G28.

Keywords: regulatory surveillance; incomplete enforcement; heterogeneous bank model; prompt corrective action, bank capital ratio; credit crunch.

\footnotetext{
* The authors especially thank for the valuable comments and discussions by Daisuke Ikeda, Masami Imai, Hitoshi Inoue, Yuta Kajita, Mami Kobayashi, Ryuichi Nakagawa, Wataru Ohta, Toshitaka Sekine, Shigenori Shiratsuka, Naoto Soma, Nao Sudo, Koji Takahashi, and seminar participants at the Bank of Japan, Columbia University, and 2019 Kansai Monetary Economics Workshop, and conference participants at 2019 Japanese Economic Association Autumn Meeting. The authors acknowledge financial support from a Grant-in-Aid from the Ministry of Education, Science, Sports and Culture.

${ }^{\dagger}$ Imafuku-higashi 1-14-18, Joto, Osaka, Zip 536-0002, Japan, E-mail: nakakiyo1027@gmail.com

${ }^{\ddagger}$ Correspondence to Toshiaki Ogawa, 1-26-1 Toyotama-kami, Nerima-ku, Tokyo, Zip 176-8534, Japan, e-mail: toshiaki.ogawa@cc.musashi.ac.jp
} 
1. Introduction The financial crisis from 2007 through 2009 prompted a debate about bank regulation reforms, because the pre-crisis microprudential policies failed to cope with large financial shocks. Accordingly, the new Basel III regulations propose a raise in bank capital requirements. Considering preemptive microprudential policies for the stability of the banking system, an active debate is on monitoring bank capital conditions as "ex-ante" regulatory policies to reduce the cost of bank bailouts to the government. This study theoretically and empirically examines the effect of strengthening bank capital supervision on bank behavior by addressing its impact on bank heterogeneity in lending, capital accumulation, charter value, and default decisions from both short- and long-run perspectives. Our study contributes not only to a paucity of theoretical literature analyzing prudential regulations on bank capital requirements in heterogeneous dynamic models of banking (De Nicolò et al. (2014) and Corbae and D'Erasmo (2021)), but also to empirical literature analyzing its causal impact on bank behavior (Bernanke and Lown (1991) and Peek and Rosengren (1995)).

We begin by designing an equilibrium model consistently with standard corporate finance setups adapted to the peculiarities of banks (Flannery (2012)). In these setups, three features characterize our model. First, we incorporate the traditional idea of "incomplete enforcement" of regulations into modeling the strengthening bank capital supervision. The literature on incomplete enforcement of regulations considers that some firms will choose not to comply with regulations, depending on the probability of inspection and the size of penalties (e.g., Stigler (1970), Polinsky and Shavell (1979), Jones (1989), Garvie and Keeler (1994), and Shleifer (2005)). We explicitly model the strength of the financial agency's capital regulatory pressure, as their inspection/monitoring effort, that is, we describe this type of effort as the probability that bank capital regulators inspect and then detect whether banks violate the capital regulation and are undercapitalized. However, previous studies, including De Nicolò et al. (2014), model capital regulation as prudential, which cannot be violated. In our model, penalties correspond to external equity issuance by undercapitalized banks. We construct the model, so that if regulators inspect banks and find that they do not meet the capital requirement, such undercapitalized banks must issue new equity, which is costly, because of informational asymmetries. Our model allows us to pin 
down bank behavior before and after strengthening regulatory surveillance, for example, introducing prompt corrective action (PCA) policies, such that the degree of inspection effort is set to a particular value as the probability of inspection, in a dynamic analysis from incomplete to complete enforcement of capital regulations. ${ }^{1}$ To our knowledge, this study is the first to explicitly model the strength of regulatory pressure, as the degree of inspection effort in banking system dynamics.

Second, we consider banks whose regulatory capital is not necessarily constrained to their capital requirements. In our model, banks face idiosyncratic profitability shocks to their assets and equity issuance is costly because of informational asymmetries. In these environments, equity capital absorbs losses from the banks' assets, and thereby, protects their charter value when their assets' valuation experiences negative shocks. ${ }^{2}$ To this end, we model the capital regulation as "occasionally binding," whereas most previous studies model it as "always binding." Thus, our model allows us to analyze an equilibrium in which banks accumulate capital buffers by retaining their profits beyond the required level because of their precautionary motives, irrespective of whether capital regulation is incompletely enforced or not. With stricter regulatory surveillance, banks increase their capital buffers to prevent violation of capital requirements. Based on this theoretical insight, we empirically examine how the introduction of the PCA changes the agency's regulatory pressure by checking the difference in the level of capital buffers before and after such introduction.

Third, our model effectively endogenizes the amount of deposits; therefore, the size of banks' balance sheet is flexibly changed by the strength of regulatory pressure. By contrast, in the model of DeNicolo et al. (2014), the amount of deposits is an exogenous variable; consequently, in their models, banks cannot adjust the size of their balance sheets flexibly,

\footnotetext{
${ }^{1}$ As discussed in Section 3, bank capital regulations had been "softly implemented" or "incompletely enforced" before the introduction of the PCA in the U.S. in the early 1990s (Jones and King (1995)) and in Japan in the late 1990s (Kanaya and Woo (2000)). In this environment, regulators overlooked some undercapitalized banks in the incomplete enforcement of capital regulations. However, in implementing the PCA, regulators began examining the financial conditions of banks more seriously, requesting banks to self-assess their assets rigorously. Taking these facts into account, we model the PCA as an "ex-ante" capital regulation before violating the capital requirement, while previous studies such as Elizalde and Repullo (2007) and DeNicolo et al. (2014) model it as "ex-post" regulation after violating the capital requirements. The implications from our banking model involve dynamics in bank behavior before and after the introduction of the PCA as an ex-ante capital regulation.

2 Thus, our model can address the economic capital of banks (see Elizalde and Repullo (2007)).
} 
even if capital regulation tightens and banks' funding cost increases. ${ }^{3}$ As our primary interest is how the strengthening of regulatory pressure changes bank behavior, including its lending, it is more appropriate to model the amount of deposits to be endogenously determined in response to the degree of regulatory pressure.

Our dynamic model of heterogeneous banks derives the following theoretical insights into the impact of strengthening capital regulation on bank behavior: in the short run, highleverage banks with high profitability, which are more likely to violate capital requirements, respond to strengthening capital regulation. These high-leverage banks are more likely to decrease lending, as they attempt to meet the capital requirement by contracting lending. Some banks choose to default, as their charter value (market value of capital) drops below zero. Thus, strengthening regulatory surveillance can temporarily cause a credit crunch and financial instability, albeit gradually raising regulatory capital by retaining profits. In contrast, in the long run, high-leverage banks accumulate sufficient regulatory capital to the point they are no longer capital constrained, and achieve financial stability such that banks' default rate in post-PCA is lower than that in pre-PCA. Thus, accumulation of regulatory capital because of strengthening capital regulation contributes to the stability of the overall banking system.

Note that our dynamic model of banking has two different implications about the role of strengthening capital regulation in stabilizing the banking system from the short- and longrun perspectives. Our short-run implication on capital building by banks after strengthening capital regulation supports the following argument by Sarin and Summers (2016): stricter capital regulation causes financial institutions to increase measures of regulatory capital. However, such increase in regulatory capital is offset by a decline in the franchise value of the financial institutions, and thus, the banking system becomes fragile, that is, "measures of regulatory capital are flawed" (see also Atkeson et al. (2018), Begenau et al. (2019), and Atkeson and d'Avernas (2020) for other theoretical explanations). ${ }^{4}$ Indeed,

\footnotetext{
${ }^{3}$ More precisely, in the model of DeNicolo et al. (2014), the amount of deposits follows an exogenous $\mathrm{AR}(1)$ process.

${ }^{4}$ Like us, these three studies also develop models of heterogeneous banks that explain the different movements of market leverage and book leverage. Atkeson et al. (2018) and Atkeson and d'Avernas (2020) attribute the main driver of this different movement to changes in returns to bank owners from risk taking backed by government guarantees. In Begenau et al. (2019), the difference between the book
} 
Figure 1 shows that in Japan, the divergence between regulatory capital and the market value of capital occurred simultaneously with the introduction of the PCA program, which went into preliminary implementation in FY 1997 and took full effect in April 1998. Moreover, as discussed above, our model also provides new insight into the role of microprudential capital regulation in terms of its long-run consequence on the stability of the banking system.

Next, we test the short-run implications of our dynamic model by utilizing, as a quasinatural experiment, the introduction of the PCA program in Japan, which requested banks to rigorously self-assess their assets to lessen forbearance (Kanaya and Woo (2000)), similar to the PCA in the U.S. (Jones and King (1995)). Several empirical studies focusing on the direct link between explicit regulatory enforcement actions and the shrinkage of bank loans revealed that banks subject to the PCA reduced their loans at a significantly faster rate than those that were not (see Peek and Rosengren (1995) for the U.S. case). Woo (2003) and Watanabe (2007) found empirical support for the credit crunch hypothesis in fiscal year 1997, or March 1998, by demonstrating a positive and statistically significant correlation between new lending growth and bank capital. These papers attributed their results to the following fundamental changes in the Japanese financial system that year: the substantial strengthening of the supervisory and regulatory framework, and the following heightened scrutiny of the Japanese banks by the financial market (Ito and Harada (2005)).

However, such attribution of the credit crunch to the strengthening of bank capital regulations is not based on any formal theoretical predictions. Our theoretical predictions can establish the more formal lending channel of the strengthening capital regulations in terms of how they affect bank behavior, including lending and capital building as well as their charter value. Using bank-level panel data and bank-firm loan-level matched data, we employ some empirical specifications for causal inference, finding that the preliminary implementation of the PCA in FY 1997 decreased charter value and lending among highly

value and market value of equity arises because the book value of loans does not recognize losses caused by credit shocks immediately, while the market value of loans does. The advantage over these models is that our model endogenizes the bank balance sheet structure and introduces persistent idiosyncratic credit shocks, thereby, providing cross-sectional implications for heterogeneous bank behavior before and after the strengthening of supervisory pressure. 
profitable and/or leveraged banks more substantially, albeit increasing the regulatory capital of the overall banks and decreasing their charter value and loans on average. This result is consistent with our short-run theoretical predictions.

Our paper is organized as follows. Section 2 develops a dynamic model with heterogeneous banks and then derives theoretical implications regarding the causal impacts of strengthening bank capital regulations on bank behavior. Section 3 explains our empirical design and the dataset based on the PCA in Japan. Section 4 reports the results of our empirical analysis. Section 5 offers conclusions.

2. Dynamic Model with Heterogeneous Banks We now develop a dynamic model of banking to investigate the impact of increasing surveillance pressure by the government on banks' decision making in terms of capital structure and lending.

2.1. Environment The economy consists of islands (measure one) indexed by $i$. An island can be similar to an industry or a state (or a prefecture in Japan). Importantly, as will become clear, there is an idiosyncratic shock specific to $i$ that cannot be diversified away. Each island has its own bank that supplies credit monopolistically to firms on the island. ${ }^{5}$

At the end of period $t-1$, the bank on the island $i$ with its equity $e_{t}$ (we write $e_{t}$ rather than $e_{t}^{i}$ : index $i$ is omitted hereafter) chooses the amount of dividends $\pi_{t}$ to pay to its owner (banker) and the amount of bank capital to hold in the next period; ${ }^{6}$

$$
n_{t}=e_{t}-\pi_{t}>0
$$

where $e_{t}$ is the bank equity capital before the dividend distribution, while $n_{t}$ is the bank equity capital after the dividend distribution. We call $n_{t}$ as "ex-ante" equity capital and $e_{t}$ as "ex-post" equity capital, because the former can be adjusted by the bank before the

\footnotetext{
${ }^{5}$ We do not model firms explicitly. Rather, we assume that banks face their own loan demand, and given this demand, they maximize their profits. This assumption fits well, especially for Japanese commercial banks until the late 1990s, when the regulatory capital surveillance strengthened. Until the late 1990s, there were a few local commercial banks in each prefecture in Japan, and they lent exclusively to local firms in the Japanese main bank system (Aoki and Patrick (1994)).

${ }^{6}$ We assume that ex-ante equity capital cannot be negative, because if it is negative, a bank run occurs and the regulator closes the bank, in line with Elizalde and Repullo (2007).
} 
credit shock (introduced below) occurs, while the latter cannot. We permit banks to issue new equity (i.e., $\left.\pi_{t}<0\right)$. In this case, it costs the bank $(1+a)$ per unit of equity to issue because of problems caused by the informational asymmetry between equity issuers and investors (Bolton and Freixas (2006)). ${ }^{7}$

At the beginning of period $t$, the bank chooses the amount of deposits $d_{t}$ to gather, and loans $l_{t}$ to give (i.e., prepares the balance sheet), satisfying the following balance sheet constraint;

$$
l_{t}=n_{t}+d_{t}
$$

After preparing the balance sheet (intermediate stage of period $t$ ), with probability $p$, the regulator approaches the bank and inspects whether the bank meets the capital requirement;

$$
\phi_{t} \equiv \frac{n_{t}}{l_{t}} \geq \bar{\phi}
$$

where $\phi_{t}$ is the ex-ante equity capital to the loans ratio, and $\bar{\phi}$ is the required level. If the regulator finds that the bank does not meet the requirement, the bank needs to issue new equity, $\bar{\phi} l_{t}-n_{t}$, to satisfy the requirement, which costs the bank $(1+a)\left(\bar{\phi} l_{t}-n_{t}\right){ }^{8}$

Then, an idiosyncratic shock specific to the island, $z_{t+1}$, occurs to the quality of credits, and revenue $z_{t+1} f\left(l_{t}\right)$ is realized. $f(\cdot)$ is the revenue function of loans that satisfies $f(0)=0$, $f>0, f^{\prime}>0$, and $f^{\prime \prime}<0$ in line with DeNicolo et al. (2014). ${ }^{9}$ Credit shocks $z_{t+1}$ are i.i.d. across islands (banks) and follow an AR(1) process;

$$
\log z_{t+1}=(1-\rho) \overline{\log z}+\rho \log z_{t}+\epsilon_{t+1}
$$

7 This reduced-form modeling of equity issuance cost is in line with Cooley and Quadrini (2001), Hennessy and Whited (2007), and Corbae and D'Erasmo (2021).

8 This formulation means that banks replace deposits with equity capital, rather than decrease loans, to satisfy the requirement at the intermediate stage. This assumption is based on the fact that loans are illiquid, while deposits are liquid.

${ }^{9}$ In DeNicolo et al. (2014), credit shocks are aggregate (systemic) shocks. In contrast to DeNicolo et al. (2014), we assume that credit shocks are idiosyncratic in order to study the cross-sectional implications between profitability, capital accumulation, and capital constrained lending behavior of banks. These idiosyncratic shocks generate a rich cross-sectional distribution of bank capital structure. 
where $\epsilon_{t} \sim N\left(0, \sigma^{2}\right)$.

At this moment, banks choose whether to default on the deposits and exit, or repay and continue their businesses. If a bank chooses to default, its value is zero because of limited liability. When the bank chooses to continue, it repays the deposits (i.e., the bank clears the balance sheet). Then, equity capital at the end of period $t$ (ex-post equity capital), $e_{t+1}$, is realized as;

$e_{t+1}=\left\{\begin{array}{lc}E^{N}\left(l_{t}, n_{t} ; z_{t+1}\right) \equiv z_{t+1} f\left(l_{t}\right)-R^{d} \underbrace{\left(l_{t}-n_{t}\right)}_{\equiv d_{t}}-k \text { if not inspected (with prob. } 1-p), \\ E^{I}\left(l_{t}, n_{t} ; z_{t+1}\right) & \text { if inspected (with prob. } p \text { ) },\end{array}\right.$

where $E^{I}\left(l_{t}, n_{t} ; z_{t+1}\right)$ is defined as follows;

$$
E^{I}\left(l_{t}, n_{t} ; z_{t+1}\right) \equiv \begin{cases}E^{N}\left(l_{t}, n_{t} ; z_{t+1}\right) & \text { if } \phi_{\mathrm{t}} \geq \bar{\phi} \\ E^{N}\left(l_{t}, n_{t} ; z_{t+1}\right)-\left(1+a-R^{d}\right)\left(\bar{\phi} l_{t}-n_{t}\right) & \text { if } \phi_{\mathrm{t}}<\bar{\phi}\end{cases}
$$

In equation $(5), E^{N}\left(l_{t}, n_{t} ; z_{t+1}\right)$ is the ex-post equity capital of the bank with the credit shock $z_{t+1}$, if the bank is not inspected by the regulator, which occurs with the probability $1-p . R^{d}$ is deposit rate, and $k$ is the fixed operating cost in the loan market.

$E^{I}\left(l_{t}, n_{t} ; z_{t+1}\right)$ is the ex-post equity capital of the bank inspected by the regulator. If inspected, the situation can be divided into two cases, as shown in (6). If the bank satisfies the capital requirement $\left(\phi_{t} \geq \bar{\phi}\right)$, its ex-post equity capital is the same as $E^{N}\left(l_{t}, n_{t} ; z_{t+1}\right)$. However, if it does not satisfy the requirement $\left(\phi_{t}<\bar{\phi}\right)$, the undercapitalized bank needs to issue new equity up to $\bar{\phi} l_{t}$, which costs it $(1+a)\left(\bar{\phi} l_{t}-n_{t}\right)$. Consequently, its ex-post equity capital becomes $E^{N}\left(l_{t}, \bar{\phi} l_{t} ; z_{t+1}\right)-(1+a)\left(\bar{\phi} l_{t}-n_{t}\right)=E^{N}\left(l_{t}, n_{t} ; z_{t+1}\right)-\left(1+a-R^{d}\right)\left(\bar{\phi} l_{t}-n_{t}\right)$. This expression means that issuing equity decreases the ex-post equity capital to the extent that issuing equity is more costly than collecting deposits. Thus, issuing equity at the intermediate stage decreases bank value at the end of the period. Banks increase their ex-ante equity capital by retaining their profits to avoid this penalty for not complying with regulation (i.e., costly external equity issuance by undercapitalized banks), when the 
surveillance pressure is strengthened, or inspection probability $p$ increases.

Figure 2 summarizes the events, bank actions, and the changes in the bank balance sheet, along the timeline.

2.2. Bank Problem and Stationary Equilibrium In period $t$, the bank's objective function is the expected discounted value of dividends;

$$
E_{t} \sum_{i=0}^{\infty} \beta^{i} \Theta\left(\pi_{t+i}\right)
$$

where an expectation operator $\left(E_{t}\right)$ is used with respect to the credit shocks $z_{t+1}, \beta$ is the banker's discount factor, and $\Theta(\cdot)$ is the function;

$$
\Theta(\pi)= \begin{cases}\pi & \text { if } \pi \geq 0 \\ \pi(1+a) & \text { if } \pi<0\end{cases}
$$

which indicates that equity issuance is costly, as mentioned above. The parameter $a$ is the equity issuance cost, as introduced in subsection 2.1.

We now formulate the bank problem recursively and define the equilibrium.

2.2.1. Bank Decision Making At the end of period $t-1$, a bank with equity capital $e_{t}$ and idiosyncratic credit shock $z_{t}$ chooses $\left\{\pi_{t}, l_{t}, d_{t}, n_{t} \geq 0, \phi_{t}\right\}$ to solve the following recursive problem;

$$
\begin{aligned}
V\left(e_{t} ; z_{t}\right)=\max & \Theta\left(\pi_{t}\right)+\beta \cdot[p \underbrace{p \sum_{z_{t+1}} P\left(z_{t} \mid z_{t+1}\right) \max \{\underbrace{V\left(E^{I}\left(l_{t}, n_{t} ; z_{t+1}\right) ; z_{t+1}\right)}_{\text {repay }\left(x^{I}=0\right)}, \underbrace{0}_{\text {default }\left(x^{I}=1\right)}\}}_{\text {inspected by regulator }} \\
+ & \underbrace{\left.(1-p) \sum_{z_{t+1}} P\left(z_{t} \mid z_{t+1}\right) \max \{\underbrace{V\left(E^{N}\left(l_{t}, n_{t} ; z_{t+1}\right) ; z_{t+1}\right)}_{\text {repay }\left(x^{N}=0\right)}, \underbrace{0}_{\text {default }\left(x^{N}=1\right)}\}\right],}_{\text {not inspected }}(9)
\end{aligned}
$$

subject to constraints $(1),(2),(3),(4),(5),(6)$, and (8), where $V\left(e_{t} ; z_{t}\right)$ is the value of the bank at the end of the period $t-1$, and $P\left(z_{t} \mid z_{t+1}\right)$ is the transition matrix of credit shocks 
from $z_{t}$ to $z_{t+1}$. We define the default policy $X\left(e_{t} ; z_{t}, z_{t+1}\right)$, which is contingent on whether the bank is inspected, and the realized credit shock $z_{t+1}$ as follows;

$$
X^{i}\left(e_{t} ; z_{t}, z_{t+1}\right)=\left\{\begin{array}{cl}
0 & \text { Repay and Continue } \\
1 & \text { Default and Exit }
\end{array}\right.
$$

where $i \in\{\mathrm{I}$ (inspected), N (not inspected)\}. We express the other policy functions of the bank, as the solutions of the above decision problem as follows;

$$
\begin{aligned}
\pi_{t} & =\Pi\left(e_{t} ; z_{t}\right), \\
l_{t} & =L\left(e_{t} ; z_{t}\right), \\
d_{t} & =D\left(e_{t} ; z_{t}\right), \\
n_{t} & =N\left(e_{t} ; z_{t}\right), \\
\phi_{t} & =\Phi\left(e_{t} ; z_{t}\right) .
\end{aligned}
$$

2.2.2. Entry of New Banks and Stationary Distribution We assume if a bank with a state $\left(e_{t} ; z_{t}\right)$ defaults and exits the market, it is replaced with a new bank with the state $\left(e_{t}=0 ; z_{t}\right){ }^{10}$ This means that a new bank has zero equity capital, and initially, it has to use costly external finance to raise capital to meet the capital requirement. Using the policy functions in subsection 2.2.1, we can express the law of motion of the distribution $\zeta_{t}\left(d e ; z_{i}\right)$ as follows:

$$
\begin{aligned}
\zeta_{t+1}\left(d e^{\prime} ; z_{j}\right)= & \int \sum_{i} P\left(z_{i} \mid z_{j}\right) \cdot \zeta_{t}\left(d e ; z_{i}\right) \cdot\left[\left\{p \cdot \mathrm{I}\left\{x^{I}\left(e ; z_{i}, z_{j}\right)=0\right\} \cdot \mathrm{I}\left\{\phi\left(e ; z_{i}\right) \geq \bar{\phi}\right\}\right.\right. \\
& \left.+(1-p) \cdot \mathrm{I}\left\{x^{N}\left(e ; z_{i}, z_{j}\right)=0\right\}\right\} \cdot \mathrm{I}\left\{d e^{\prime} \ni E^{N}\left(L\left(e ; z_{i}\right), N\left(e ; z_{i}\right) ; z_{j}\right)\right\} \\
& \underbrace{+p \cdot \mathrm{I}\left\{x^{I}\left(e ; z_{i}, z_{j}\right)=0\right\} \cdot \mathrm{I}\left\{\Phi\left(e ; z_{i}\right)<\bar{\phi}\right\} \cdot \mathrm{I}\left\{d e^{\prime} \ni E^{I}\left(L\left(e ; z_{i}\right), N\left(e ; z_{i}\right) ; z_{j}\right)\right\}}_{\text {Incumbent banks }}
\end{aligned}
$$

\footnotetext{
10 This assumption ensures that there always exists one bank on each island, and the aggregated measure of banks over islands is exactly one.
} 


$$
\begin{aligned}
& +\left\{p \cdot \mathrm{I}\left\{x^{I}\left(e ; z_{i}, z_{j}\right)=1\right\} \cdot \mathrm{I}\left\{\Phi\left(e ; z_{i}\right) \geq \bar{\phi}\right\}+(1-p) \cdot \mathrm{I}\left\{x^{N}\left(e ; z_{i}, z_{j}\right)=1\right\}\right. \\
& \underbrace{\left.\left.+p \cdot \mathrm{I}\left\{x^{I}\left(e ; z_{i}, z_{j}\right)=1\right\} \cdot \mathrm{I}\left\{\Phi\left(e ; z_{i}\right)<\bar{\phi}\right\}\right\} \cdot \mathrm{I}\left\{d e^{\prime} \ni 0\right\}\right]}_{\text {New entrants }},
\end{aligned}
$$

where $\mathrm{I}\{\cdot\}$ is an indicator function, and $E^{i}(l, n ; z)(i \in\{I, N\})$ is the function in (5) and (6). The initial terms of the right-hand side represent the distribution of incumbent banks, and the later terms represent new entrants with zero capital, which replace the defaulting banks. A stationary distribution is $\zeta^{*}$ satisfying $\zeta_{t+1}=\zeta_{t}=\zeta^{*}$ (invariant distribution).

2.2.3. Definition of Stationary Equilibrium Given the policy parameter for capital requirement $\bar{\phi}$, inspection probability $p$, bank revenue function $f(\cdot)$, the process of credit shocks $z_{t}$, and deposit rate $R^{d}$, a stationary equilibrium of the banking industry is a set of

1. policy and value functions for banks $\left\{X^{i}\left(e ; z, z^{\prime}\right), \Pi(e ; z), L(e ; z), D(e ; z), N(e ; z)\right.$, $\Phi(e ; z), V(e ; z)\}$ that satisfy the bank problem,

2. stationary distribution of banks $\zeta^{*}(e ; z)$ implied by the policy functions that are derived in item 1.

2.3. Calibration and Model Implications We now present the results of the calibration and simulation of the model to derive theoretical and cross-sectional predictions for the strengthening regulatory pressure, that is, increasing the inspection probability $p$ in the incomplete enforcement of capital regulation. To calibrate the model, we use yearly panel data of Japanese commercial banks; hence, the model period is set to be one year.

2.3.1. Credit Shock First, we calibrate the dynamics of credit shocks. Following De Nicolò et al. (2014), we proxy the shock process by the return on bank assets (ROA) before taxes; hence, $z$ in subsection 2.1 corresponds to ROA. The sample period is fiscal years 1975 through 1996, just before the preliminary implementation of the PCA in FY 1997, which took full effect in April 1998, to Japanese commercial banks. We estimate the following 
$\mathrm{AR}(1)$ process of $\mathrm{ROA}_{i t}$ for bank $i$ in period $t$ :

$$
\log \mathrm{ROA}_{i t}=(1-\rho) \log \mathrm{ROA}_{0}+\rho \log \mathrm{ROA}_{i t-1}+\gamma_{i}+u_{i t}
$$

where $\gamma_{i}$ is the bank fixed effects, and $u_{i t}$ is i.i.d. and distributed $N(0, \sigma)$. The middle panel of Table 1 shows the results. We then apply the method of Tauchen (1986) to the $\mathrm{AR}(1)$ process in equation (17) to obtain a finite state Markov process $P\left(z_{t} \mid z_{t+1}\right)$.

2.3.2. Equity Issuance Cost and Inspection Probability Next, we jointly calibrate the parameters, fixed cost $(k)$, equity issuance cost $(a)$, and inspection probability $(p)$. Let us denote the inspection probability before and after increasing inspection/monitoring efforts as $p_{0}$ and $p_{1}\left(p_{0}<p_{1}\right)$, respectively. We assume that other parameters (i.e., economic conditions) do not change.

Table 2 shows the change in averaged capital surplus, defined as capital ratio minus the required capital level, before and after the strengthening of capital supervision; the preliminary implementation of the PCA in FY 1997 and its full effect in FY 1998 (see Section 3 for more details). Note that because of weak regulatory pressure, or incomplete enforcement, banks had relatively lower capital surplus (around 1\%) before the preliminary implementation in FY 1997. However, after the preliminary implementation, banks accumulated capital surplus gradually, by retaining profits; consequently, it reached approximately $4 \%$, much higher than $1 \%$ during pre-strengthening.

We assume that after the preliminary implementation of the PCA in FY 1997, the enforcement is complete, that is, $p_{1}=1$, which means that regulators rigorously inspect all banks. This implies that if bank capital ratio is below the required level, undercapitalized banks need to issue new equity capital by incurring extra cost $a$ per unit of issued equity, for certain, to satisfy the requirement. Under this assumption, we calibrate fixed cost $(k)$, equity issuance cost $(a)$, and the inspection probability before the implementation of the PCA $\left(p_{0}\right)$ by targeting the bank default rate, capital surpluses before and after the implementation of the PCA, respectively. Tables 1 and 3 show model parameters and target moments.

\subsubsection{Banks' Value Functions and Policy Functions Figures 3 to 7 illustrate the}


change in bank value functions and policy functions for default, capital ratio, dividends, and loans, with the strengthening of surveillance pressure, that is, the inspection probability increases from $p_{0}=0.25$ (solid lines before) to $p_{1}=1$ (dashed lines after). There are two state variables, namely, the ex-post equity capital $e_{t}$ (i.e., equity capital at the end of period $t$ ), and the credit shock $z_{t}$. Hence, value functions and policy functions are functions of these two state variables. We discretize credit shocks $z_{t}$ into 11 states $\left(z_{1}, z_{2}, \ldots, z_{11}\right)$. $z_{1}$ is the worst (smallest) credit shock and $z_{11}$ is the best (largest) credit shock. We report only the relevant values and policy functions in those states.

Figure 3 demonstrates that banks' value decreases after inspection probability increases. This reduction is larger for banks with better credit shocks $\left(z_{9}\right.$ and $\left.z_{11}\right)$ and smaller equity capital. For highly profitable and/or leveraged banks, the capital requirement is more binding than that for other banks; hence, strengthening the surveillance pressure damages the value of such banks more seriously than it does others. ${ }^{11}$ We can interpret banks' value as their charter value, or market value of capital. This implies that strengthening regulatory surveillance would damage banks' charter value and increase their default incentives, which can lead to financial instability, as shown later in subsection 2.4.

Figure 4 reports bank default policies. Banks with the best credit shocks $\left(z_{11}\right)$ never choose to default because they have significant charter value (as Figure 3 shows, their charter value is greater than zero in all region of equity $e_{t}$ ). As for banks with relatively bad shocks $\left(z_{1}, z_{9}\right)$ and smaller equity capital, their default thresholds for equity capital increase; therefore, they are more likely to default when the inspection probability increases, that is, after the strengthening of surveillance pressure, their charter value decreases (see Figure 3), so that their default incentives increase. Consequently, the banking sector becomes temporarily vulnerable.

Figure 5 shows bank decisions for capital ratio. Banks with relatively good credit shocks $\left(z_{6}\right.$ and $\left.z_{11}\right)$ tend to violate capital requirements when the inspection probability is low $\left(p_{0}\right)$.

\footnotetext{
${ }^{11}$ A more detailed mechanism is that the capital requirement prevents some banks from increasing their asset to the point in which their marginal profit of asset and marginal cost of funding (deposit rate) be equalized; consequently, the capital requirement is more binding for banks with higher marginal profit of asset. This is similar to the mechanism through which firms with larger marginal product of capital are more likely to be borrowing constrained, as demonstrated in the literature on capital misallocation (e.g., Hsieh and Klenow (2009), Midrigan and Xu (2014), and Moll (2014)).
} 
They start to hold the minimum level of capital ratio required (i.e., $\bar{\phi}=0.08$ ) after the inspection probability increases. Banks with the best credit shocks $\left(z_{11}\right)$ and insufficient equity (e) keep violating the capital requirement, even after the inspection probability increases. This is because they have such large profitability that they expect high profits, and only issue equity ex-post after the regulatory inspection at the expense of some of those profits, rather than increase capital ratio through costly equity issuance ex-ante before the regulatory inspection. ${ }^{12}$ For banks with the worst credit shocks $\left(z_{1}\right)$, capital requirements are not binding, even if the inspection probability is low $\left(p_{0}\right)$. Such banks hardly change their capital policy, even if the inspection probability increases, because they have already accumulated sufficient capital buffers.

Figure 6 reports dividend policies. Negative dividends mean equity issuance. When the inspection probability is low $\left(p_{0}\right)$, banks with the best credit shocks $\left(z_{11}\right)$ and sufficient equity capital $(e)$ are more likely to allot their profits as dividends; consequently, they are more likely to violate the capital requirement in incomplete enforcement of regulations, as Figure 5 shows. However, after the inspection probability increases, they retain their profits and accumulate their capital buffers, which correspond with the expansion of the plateau region in Figure 6. After they accumulate sufficient capital buffers so as not to violate the capital requirement, they start to pay their dividends again.

Figure 7 demonstrates the changes in banks' lending policies when the inspection probability increases. Banks with better credit shocks $\left(z_{9}\right.$ and $\left.z_{11}\right)$ and smaller equity capital (e) contract their credit supplies more substantially than do other banks. This is because, for those highly profitable and/or leveraged banks, capital requirements are more likely to be binding, and it is less costly for them to reduce their ex-ante credit supply rather than to issue new equity capital ex-post after the regulatory inspection. ${ }^{13}$ Banks with the worst credit shocks $\left(z_{1}\right)$ hardly change their credit supply because they have already accumulated sufficient equity capital.

\subsubsection{Stationary Distribution of Capital Ratio Figure 8 shows stationary distri-}

\footnotetext{
12 However, as Figure 8 shows, the proportion of banks that violate the capital requirement is small in equilibrium, in particular, after strengthening capital surveillance.

13 Note that the equity raising policy of the least profitable banks is almost unchanged before and after the inspection probability increases, as Figure 5 shows.
} 
bution of capital ratio, when the regulatory capital surveillance is incompletely enforced $\left(p=p_{0}(=0.25)\right)$ and completely enforced $\left(p=p_{1}(=1)\right)$, respectively. As the inspection probability is low $\left(p=p_{0}\right)$, many banks choose not to comply with the capital regulation $(\bar{\phi}=0.08)$. After increasing the inspection probability $\left(p=p_{1}(=1)\right)$, almost all banks satisfy the capital regulation by accumulating profits.

\subsection{Dynamic Analysis from Incomplete to Complete Enforcement We now} turn to the dynamic analysis from incomplete to complete enforcement of capital regulation, in which the inspection probability increases from $p_{0}(=0.25)$ to $p_{1}(=1)$. Our dynamic analysis examines the development of aggregate variables (such as the total amount of loans, default rate of banks, and capital ratio) over time, after the inspection probability increases from $p_{0}$ to $p_{1}$. We assume that initially the economy is at the stationary equilibrium of $p_{0}$ (i.e., the incomplete enforcement of the capital regulation). The probability increases to $p_{1}(=1)$ (i.e., the complete enforcement of capital regulation) unexpectedly, at the intermediate stage of period $t=10$, that is, the announcement of the complete enforcement of capital regulation occurs before banks decide on whether to default or not at $t=10$. The economy transits from the initial stationary equilibrium $\left(p_{0}\right)$ to the final stationary equilibrium $\left(p_{1}\right)$. Figure 9 reports the results.

Following the increase in inspection probability, banks accumulate capital buffers, as panel (a) shows. As external equity issuance is costly, banks gradually accumulate profits and increase their capital ratio over time.

As panel (b) shows, banks cut dividends in response to the increase in inspection probability. Dividend distribution recovers gradually; however, it does not return to the original level, as banks are forced secure a larger proportion of their profits than before the strengthening of capital regulation.

The average of market capital ratio (panel (c)) appears to move in the same way as their dividends. ${ }^{14}$ In contrast to the regulatory capital buffer, market capital ratio decreases following the increase in inspection probability. This contrast in movement between the regulatory and the market capital ratio (or the franchise value) demonstrates the impacts

\footnotetext{
14 The market capital ratio is franchise value / (franchise value + deposit).
} 
of strengthening capital regulation, as observed in Figure 1 for the PCA program in Japan. The regulatory capital ratio drastically increased in FY 1997 when the PCA went into preliminary implementation; however, the market value of bank capital decreased. This indicates that banks managed to increase their regulatory capital ratio by retaining their earnings after the strengthening of capital supervision, while they faced increases in their default risk (panel $(\mathrm{d})$ ), which is governed by their market value. Sarin and Summers (2016) highlight this effect for U.S. financial institutions (see also Begley et al. (2017)). ${ }^{15}$

We can confirm this by the dynamics in banks' default decisions (shown in panel $(\mathrm{d})$ ). The banking sector initially becomes unstable, as the franchise value of banks decreases; thus, they are more likely to choose default just after the inspection probability increases. However, in the long run, banks are less likely to default, and thus, the overall banking system becomes more stable than the initial steady state, as the charter value of banks recovers gradually in tandem with the gradual increase in regulatory capital. Precisely, the default rate in the steady state decreases from $0.98 \%$ to $0.73 \%$. Therefore, our dynamic model has different implications about the strengthening regulatory surveillance in stabilizing the banking system from the short- and long-run perspectives. ${ }^{16}$

The dynamic response of credit supply (panel (e)) indicates that after inspection probability increases, banks suddenly reduce loans; a credit crunch occurs. The amount of loans appears to recover gradually, with the gradual increase in bank regulatory capital buffers; however, the amount of loans does not return to the original level, as the funding costs of banks now become larger in equating the marginal profits of loans with the marginal costs of funding.

\footnotetext{
${ }^{15}$ Sarin and Summers (2016) discussed the capitalization of U.S. financial institutions as "...regulatory measures that have increased safety have been offset by a dramatic decline in the franchise value of major financial institutions, caused at least in part by these new (stricter) regulations." Begley et al. (2017) empirically showed that U.S. banks under-report their risk in their trading books when they have lower equity capital.

${ }^{16}$ Compared with the U.S. banking system, the Japanese banking system has experienced very few bank failures. However, just before and after the preliminary implementation of the PCA in FY 1997 , bank failures temporarily increased. From FYs 1996 to 1999, 14 Japanese banks including the Hokkaido Takushoku Bank and the Long-Term Credit Bank of Japan failed (the annual default rate is about 2\%), whereas after FY 2000, only four banks including the Ashikaga bank failed (the annual default rate is about $0.1 \%)$.
} 
2.5. Theoretical Predictions and Empirical Insights Based on the results for calibration thus far, and to motivate our empirical analysis in the next section, we now summarize some empirical insights on the causal impacts of strengthening capital supervision on bank behavior. 1) Highly profitable and/or leveraged banks, in the short run, are more likely to respond to the strengthening of capital regulation. Their charter value and lending will decrease more than other banks, while the overall banks accumulate regulatory capital and decrease charter value and lending on average, 2) however, in the long run, such accumulation of regulatory capital leads to the stability of the banking system. In the next section, we focus on short-run implications, empirically examining the impacts of strengthening capital supervision.

3. Empirical Design We begin by reviewing the prompt corrective action (PCA) program in Japan to utilize the PCA as a quasi-natural experiment to test our theoretical predictions about the causal impacts of strengthening bank capital supervision on bank behavior. We then introduce empirical specifications for the following bank outcome variables: regulatory capital ratios, franchise values, and bank loans.

\subsection{PCA in Japan: Increase in Regulatory Pressure in FY 1997 We now review} the PCA program in Japan for the empirical analyses in the following sections.

The Japanese authorities established the PCA framework under the "Law to Ensure Financial Institution Soundness," loosely modeled after the U.S. framework (see Kanaya and Woo (2000). For the enforcement of the PCA in the U.S., see Jones and King (1995)). The PCA, which was to take full effect in April 1998, went into preliminary implementation in FY 1997. The PCA has two main components.

First, it introduces a self-assessment process that holds the banks responsible for valuing their assets prudently and realistically, according to well-defined guidelines. These procedures also require that the banks' own findings (including the necessary provisioning for loan losses and capital ratios) be subject to review by external auditors and inspection and monitoring by bank examiners.

Second, the PCA also specifies the thresholds of the regulatory capital ratio under which the regulators can force the banks to take remedial actions. These remedial actions 
range from reduction of branches to reduction of dividends and liquidation in the case of insolvency. In addition, in FY 1997, the authorities announced that the Financial Supervisory Agency (FSA) would take over the role of banking supervision from the Ministry of Finance. The FSA was granted autonomy and independence to allow its supervisors to operate more effectively. The FSA started operations in April 1998.

By removing the possibility of discretionary forbearance of bank supervisors, the PCA represented a strengthening of the existing regulatory framework at the time. ${ }^{17}$ Taking these facts into account, we regard the PCA as an "ex-ante" capital regulation before violating the capital requirement (see also footnote 1 in the Introduction). Indeed, as Woo (2003), Watanabe (2007), and Sekine and Watanabe (2018) emphasize, combined with the creation of the FSA, whose independence gave it a credibility that the Ministry of Finance lacked, the preliminary implementation of the PCA could force the weakly capitalized banks to take the capital adequacy requirement more seriously; consequently, it could trigger a credit crunch by these banks in FY 1997.

3.2. Empirical Specification As discussed in the above subsection, previous literature noted that the preliminary implementation of the PCA in FY 1997 increased regulatory pressure on Japanese banks. Based on the short-run implications of our dynamic model (see subsection 2.5), we empirically address the following three questions:

1. Did the heightened regulatory pressure in FY 1997 lead to an increase in banks' regulatory capital? If yes, did the capital increase depend on banks' holding of regulatory capital and profitability in the pre-1997 periods, or FY $1996 ?$

2. Did the heightened regulatory pressure decrease banks' franchise values? Furthermore, as our dynamic model predicts, did low capitalized and/or profitable banks

\footnotetext{
17 Kanaya and Woo (2000) provide evidence of regulatory forbearance, made possible by the weakness in the regulatory framework before FY 1997. For example, the regulatory authorities, which had the power to de-license banks, usually intervened only after banks had become insolvent. Furthermore, as shown by Skinner (2008), Japanese banks also used deferred tax assets to compensate for capital losses arising from unrealized losses on their stock holdings. They were able to do so because the government allowed them to account for their deferred tax assets as Tier I capital in 1998. Bank managers subjectively estimated their total deferred tax assets at their own discretion. The regulatory forbearance policy had allowed Japanese banks to engage in a "patching up" of their capital ratios before FY 1997 (see also Shrieves and Dahl (2003) and Nakashima and Takahashi (2018)).
} 
face higher reduction in franchise values?

3. Did the heightened regulatory pressure reduce bank lending? Furthermore, as our dynamic model predicts, did low capitalized and/or profitable banks face higher reduction in bank lending?

To examine the causal impacts of the heightened regulatory pressure in FY 1997, we use the following specification with two-way fixed effects for bank-level panel data,

$$
\begin{aligned}
\mathrm{y}_{i t}= & a_{0}+a_{1} \mathrm{BUFFER}_{i t-1}+a_{2} \mathrm{ROA}_{i t-1}+a_{3} \mathrm{BUFFER}_{i t-1} * \mathrm{ROA}_{i t-1} \\
& +a_{4} t_{1997}+a_{5} \mathrm{BUFFER}_{i t-1} * t_{1997}+a_{6} \mathrm{ROA}_{i t-1} * t_{1997} \\
& +a_{6} \mathrm{BUFFER}_{i t-1} * \mathrm{ROA}_{i t-1} * t_{1997}+a_{7} \mathrm{CONTROLS}_{i t-1}+v_{i}+\varepsilon_{i t},
\end{aligned}
$$

where the dependent variable, $\mathrm{y}_{i t}$, indicates bank $i$ 's four outcome variables for the two sample periods $t=$ FYs 1996 and 1997, that is, regulatory capital adequacy ratios, regulatory capital buffers, market capital ratios, and the growth rate of the total amount of loans outstanding. Regulatory capital buffers are defined as the difference between a bank's reported capital adequacy ratios and its regulatory target ratio ( $8 \%$ for international banks and $4 \%$ for domestic banks). We use the bank market capital ratio as a proxy of bank franchise values. The bank market capital ratio is defined as the market value of a bank's equity divided by the market value of its total assets, where the market value of a bank's total assets is defined as the sum of the market value of its equity and the book value of its total liabilities. This definition of the market capital ratio corresponds to that in our theoretical model. We calculate the market value of equity by multiplying the end-of-year stock price by the number of shares.

Observable explanatory variables, BUFFER $\mathrm{B}_{i t-1}$ and $\mathrm{ROA}_{i t-1}$, denote one-period-lagged values of the regulatory capital buffers and return on assets for bank $i$, respectively. These two variables are supposed to capture the adequacy of bank capital and profitability in the pre-1997 periods, or in FYs 1995 and 1996. $t_{1997}$ indicates the time dummy for FY 1997 to capture the impacts of the heightened regulatory pressure in FY 1997. In our empirics, we pay special attention to the time dummy and its interaction effects with the bank capital and profitability variables. 
CONTROLS $_{i t-1}$ denotes one-period-lagged values of other bank control variables: logarithmic values of total assets $\left(\mathrm{SIZE}_{i t-1}\right)$, the indicator variable regarding whether bank $i$ has overseas branches (OVERSEA $\left.{ }_{i t-1}\right)$, Tobin's $q\left(\right.$ TOBINQ $\left._{i t-1}\right)$, and their respective interaction terms with the annual growth rate of real GDP $\left(\mathrm{RGDP}_{t}\right)$ and with the annual return of the TOPIX index $\left(\right.$ STOCK $\left._{t}\right)$ as well as the two macroeconomic variables. ${ }^{18}$ The macroeconomic variables and its interaction terms control for the effects of the macroeconomic environment and its interactions other than those relevant to our special interests $t_{1997}$, BUFFER $_{i t-1} * t_{1997}, \mathrm{ROA}_{i t-1} * t_{1997}$, and BUFFER $i t-1 * \mathrm{ROA}_{i t-1} * t_{1997}$. Tobin's $q$ is defined as the ratio of the market value of bank $i$ to its book value, where the market value is defined as the sum of the market value of its equity and the book value of its total liabilities. $\mu_{i}$ denotes bank $i$ 's time-invariant fixed effects to control for its time-invariant unobservables. $\varepsilon_{i t}$ is the stochastic disturbance term.

As for using the bank-firm loan-level matched data, we introduce the following specification with the three-way fixed effects for the bank loan equation,

$$
\begin{aligned}
\operatorname{LOAN}_{i t}^{j}= & a_{0}+a_{1} \mathrm{BUFFER}_{i t-1}+a_{2} \mathrm{ROA}_{i t-1}+a_{3} \mathrm{BUFFER}_{i t-1} * \mathrm{ROA}_{i t-1} \\
& +a_{4} \mathrm{BUFFER}_{i t-1} * t_{1997}+a_{5} \mathrm{ROA}_{i t-1} * t_{1997} \\
& +a_{6} \mathrm{BUFFER}_{i t-1} * \mathrm{ROA}_{i t-1} * t_{1997}+a_{7} \mathrm{CONTROLS}_{i t-1} \\
& +a_{8} \mathrm{RELATIONS}_{i t-1}^{j}+v_{i}+u_{j t}+\varepsilon_{i t}^{j}
\end{aligned}
$$

where the dependent variable, $\Delta \mathrm{LOAN}_{i t}^{j}$, indicates the growth rate of the total amount of loans outstanding between bank $i$ and domestic listed firm $j$ for the two sample periods $t=$ FYs 1996 to 1997.

The loan-level equation (19) additionally includes as control variables one-period lags of two relationship variables RELATIONS ${ }_{i t-1}^{j}$ : lending exposure ( $\operatorname{LEXP}_{i t-1}^{j}$ ) and borrowing exposure $\left(\operatorname{BEXP}_{i t-1}^{j}\right)$. The lending exposure is defined as loans from bank $i$ to firm $j$ divided

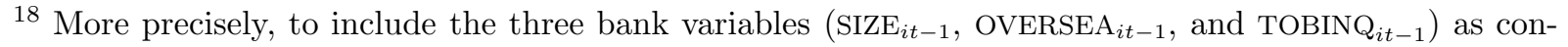
founding factors, we use the third-quarter financial reports on December 31 in defining them. As for defining the four outcome variables, the capital buffers, and return on assets, we use the fourth-quarter (i.e., the fiscal year-end) reports on March 31, which alleviates the simultaneity between the three bank variables and the bank capital-profitability variables.
} 
by the total loans of bank $i$. The borrowing exposure is defined in the same manner, as loans from bank $i$ to firm $j$ divided by the total borrowings of firm $j$. $v_{i}$ denotes bank $i$ 's time-invariant fixed effects, while $u_{j t}$ denotes firm $j$ 's time-varying fixed effects, or $t_{1996} * u_{j}$ and $t_{1997} * u_{j}$ with time dummies $\left(t_{1996}\right.$ and $\left.t_{1997}\right)$, to control for the borrowing firm's total demand factors at each sample period $t . \varepsilon_{i t}^{j}$ is the stochastic disturbance term.

Again, note that to control for borrower-side factors in the bank loan equation (19) with $u_{j t}$, we employ the fixed-effects approach proposed by Khwaja and Mian (2008) and Jiménez et al. (2012; 2014). The fixed-effects approach allows us to assume that all potential borrower-side factors are embodied in time-varying firm unobservables, which are captured by time*firm fixed effects $\left(u_{j t}\right) .{ }^{19}$

Equations (18) and (19) capture the causal impact of the preliminary implementation of the PCA in FY 1997 on each bank outcome variable, whose magnitude should depend on bank capitalization and profitability; the magnitude should be larger for highly leveraged and/or highly profitable banks, according to our theoretical prediction. Our empirical approach assumes that such a marginal impact with respect to the marginal change in bank capitalization and profitability should be observed only in FY 1997 with the interaction terms BUFFER $i t-1 * t_{1997}, \mathrm{ROA}_{i t-1} * t_{1997}$, and $\mathrm{BUFFER}_{i t-1} * \mathrm{ROA}_{i t-1} * t_{1997} \cdot{ }^{20}$

3.3. Estimation Method To estimate bank-level equation (18) with two-way fixed effects, we employ the conventional within estimation method for bank panel data of the sample period $t=$ FYs 1996 and 1997.

For estimating the bank loan equation (19) with the three-way fixed-effects, our matched lender-borrower sample is based on a continuation of the lending relationship. According to the literature on relationship banking, the continuation of a bank-firm relationship depends on both the bank's and the firm's characteristics (Ongena and Smith (2001) and

\footnotetext{
${ }^{19}$ Hosono and Miyakawa (2014), Nakashima (2016), and Nakashima et al. (2020) employed this fixedeffects approach with Japanese loan-level matched data. Nakashima (2016) examined the effects of Japan's public capital injections on bank lending, while Hosono and Miyakawa (2014) and Nakashima et al. (2020) identified the effects of unconventional monetary policies on bank loan supply.

${ }^{20}$ Our empirical specifications (18) and (19) are variants of the difference-in-difference specification with continuous treatment variables. Therefore, the estimated coefficients on the interaction terms of bank capital and ROA with the time dummy of FY 1997 can be interpreted as marginal treatment effects. Acemoglu et al. (2004) and Estevadeordal and Taylor (2013) adopt a similar approach.
} 
Nakashima and Takahashi (2020)). In other words, we must address the survivorship bias that may arise from non-random assortative matching between banks and firms. To correct for survivorship bias, we employ Heckman's (1979) two-stage regression technique. In the first stage, we conduct a probit regression of relationship survival. Then, in the second stage, we employ the estimate method developed by Abowd et al. (1999) and Andrews et al. (2008) for the regression of the difference-in-difference specification of the bank loan equation (19) with the three-way fixed-effects. ${ }^{21}$

Our probit regression includes one-period lags of four banks' characteristics such as the market leverage ratio, six firms' characteristics such as the interest coverage ratio, and three relationship factors such as the duration of the relationship between lender $i$ and borrowing firm $j$. We estimate the probit regression for the continuation of bank-firm relationships and then estimate the second-stage regression of the bank lending equation with the inverse Mills ratio. To take into account the possibility that the coefficients of the variables in the probit model are time-varying, as noted by Nakashima and Takahashi (2020), we conduct estimate the probit model year by year, that is, $t=$ FYs 1996 and 1997. The Appendix contains the details of the estimation results.

3.4. Dataset Our data come from two sources. We obtain bank-level panel data from Nikkei Digital Media Inc. The data are annual and based on financial statements reported by Japanese banks for the full year (ending in March of calendar year $t+1$ ) of their fiscal year (FY) $t$, with our regression samples covering the period from FY 1996 to FY 1997. For our analysis, we include loans from Japanese city, trust, regional and mutual banks. The sample size for our analysis is 232 with 116 Japanese banks listed on any Japanese stock exchange. Table A-1 provides summary statistics for our bank-level panel data.

The second source of data is matched bank-firm loan data from the Corporate Borrowings from the Financial Institutions Database compiled by Nikkei Digital Media Inc. The data are annual and report short-term loans (with a maturity of one year or less) and long-term ones (with a maturity of more than one year) from each financial institution for

\footnotetext{
21 This estimation method gives consistent and unbiased parameter estimates, not only for time-varying observables, but also for unobserved fixed effects. See Abowd et al. (1999) and Andrews et al. (2008) for more details.
} 
every listed company on any Japanese stock exchange, which we sum to obtain the total amount of loans outstanding. Our loan measure comprises all loans received from each financial institution for about 2,500 firms per year. When combining the bank-level panel data, we use the fiscal year-end reports by banks on March 31.

The challenge of working with loan-level data was sorting through bank mergers and restructuring in our data. We recorded all dates of bankruptcies and mergers in the Japanese banking sector. In our data, when a bank ceases to exist because of a bankruptcy, firms cease reporting that financial institution as a source of loans. If we could not find any information on a bankruptcy or merger, we filled in the zero loan data. However, if we found evidence of a bankruptcy or a merger, and firms reported loans coming from a restructured bank as coming from the prior bank, we recoded these loans as coming from the restructured bank. To calculate the loan growth of a restructured bank, we trace all the banks that predated it. Thus, if banks A and B merged in year $t$ to form bank C, bank C's loans in year $t-1$ would be set equal to the sum of the loans of banks A and B, and the growth rate of bank C's loans in year $t$ would be calculated accordingly.

The loan-level data cover about 110 banks, about 2,500 listed firms, and about 20,000 relations per year. Our data set does not include all SMEs but covers approximately $70 \%$ of the total loans of the Japanese banking sector for our sample period from FY 1996 through FY 1997. The number of observations is 42,907. Table A-2 provides summary statistics for our loan-level matched data.

4. Empirical Results We now report the estimation results for regressions (18) and (19). We then conduct a placebo test for other sample periods before the preliminary implementation of the PCA in FY 1997.

4.1. Estimation Results The left panel of table 4 reports results for the causal impacts on banks' regulatory capital building. $t_{1997}$ has significantly positive coefficients, indicating that the preliminary implementation of the PCA in FY 1997, or the increasing regulatory capital pressure in FY 1997, resulted in Japanese banks' building regulatory capital, as also observed in Table 2. This result does not depend on the use of the level (the left column) and the buffer of regulatory capital (the right column) as the outcome variable. Note that 
the interaction terms, BUFFER $i t-1 * t_{1997}, \mathrm{ROA}_{i t-1} * t_{1997}$, and $\mathrm{BUFFER}_{i t-1} * \mathrm{ROA}_{i t-1} * t_{1997}$, have significantly negative, positive, and negative coefficients, respectively. This implies that highly leveraged and/or profitable banks - banks with low regulatory capital ratios and/or high return on assets - were more likely to engage in capital building with increasing regulatory capital pressure in FY 1997.

The middle panel of Table 4 shows estimated impacts on banks' market capital ratios, which is a proxy of banks' franchise value. $t_{1997}$ has significantly negative coefficients. This implies that the preliminary implementation of the PCA in FY 1997 drove down the franchise value of banks. In addition, BUFFER ${ }_{i t-1} * t_{1997}$ has positive coefficients, $\mathrm{ROA}_{i t-1} * t_{1997}$ has negative coefficients, and $\mathrm{BUFFER}_{i t-1} * \mathrm{ROA}_{i t-1} * t_{1997}$ has a positive coefficient, indicating that highly leveraged and/or profitable banks were more likely to face a decrease in their franchise value. These results for banks' market capital ratios are consistent with our theoretical prediction.

The right panel of Table 4 reports estimated impacts on bank lending behavior obtained using the bank-level specification (the left columns) and the loan-level specification (the right columns). In the bank-level specification, $t_{1997}$ has significantly negative coefficients. This implies that the preliminary implementation of the PCA in FY 1997, or the increasing regulatory capital pressure, reduced bank credit. Furthermore, BUFFER $i t-1 * t_{1997}$ has positive coefficients, $\mathrm{ROA}_{i t-1} * t_{1997}$ has a negative coefficient, and BUFFER $i t-1 * \mathrm{ROA}_{i t-1} * t_{1997}$ has a positive coefficient, indicating that highly leveraged and/or profitable banks were more likely to cut their credit in the increasing regulatory capital pressure in FY 1997. Also note that $\mathrm{ROA}_{i t-1}$ has a positive coefficient, which implies that highly profitable banks were more likely to lend in FY 1996 before the increase in regulatory pressure; however, the increasing regulatory pressure in the PCA has a more substantially negative impact on lending by such highly profitable banks.

Summing up our empirical results, the preliminary implementation of the PCA in FY 1997, or the increasing regulatory capital pressure in Japan, decreased the charter value and lending of highly leveraged and/or profitable banks more substantially than other banks, albeit increasing the regulatory capital and decreasing the charter value and loans of the 
overall banks on average, consistent with our theoretical predictions. ${ }^{22}$

4.2. Robustness Check with Placebo Tests Thus far, our empirical approach relies on the assumption that the difference in each bank outcome variable - the regulatory capital, franchise values, and bank loans - with respect to the marginal difference in bank capitalization and profitability arises from the preliminary implementation of the PCA in FY 1997. In other words, the marginal difference in bank capitalization and profitability should not have any effects on the bank outcome variables in other sample periods. To show the robustness of our result, we conduct a placebo test, that is, we run regressions (18)-(19) using different sample periods before FY 1997, and thereby, demonstrate that the difference in the bank outcome variables occurs only before and after the PCA in FY 1997.

Table 5 shows the estimation results for the other sample periods, FYs 1994 through 1996 , indicating that not only the time dummies $\left(t_{1994}, t_{1995}\right.$, and $\left.t_{1996}\right)$, but also the interaction terms of the regulatory capital buffers $\left(\mathrm{BUFFER}_{i t-1}\right)$ and return on assets $\left(\mathrm{ROA}_{i t-1}\right)$ with the time dummies do not have significant coefficients in almost all cases. Furthermore, even significant coefficients of the interaction terms do not support our theoretical predictions. ${ }^{23}$ This implies that the marginal difference in bank capitalization and profitability before and after FY 1997 successfully captures the marginal effects of the preliminary implementation of the PCA. Therefore, in other periods, when the PCA is irrelevant, bank attributes involved with their capitalization and profitability have no marginal impacts on their behavior in a theoretically consistent manner.

\footnotetext{
${ }^{22}$ The Japanese government administered the first public capital injections into the Japanese banking sector in March 1998 for 21 banks (see Nakashima (2016)). We also include the capital injection dummies into equations (18) and (19), thereby, conducting robustness checks on our estimation results. We found that even if we include the capital injection dummy, our estimation results did not qualitatively change.

${ }^{23}$ Before Article 26 of the Banking Act was revised in FY 1996, a Japanese bank was allowed to select the international standard on capital adequacy of $8 \%$, even though it did not have overseas branches. After the revision, a Japanese bank that did not have overseas branches was forced to adopt the domestic standard of $4 \%$. For a robustness check on our estimation results, we also include a switching dummy, indicating whether a bank switched the international standard on capital adequacy to the domestic one after the revision in FY 1996, and thus, increased its capital buffers by $4 \%$. Coefficients on the switching indicator are estimated to be significant in FY 1996, while estimation results are not qualitatively different from those reported in Table 5.
} 
5. Conclusion This study examines the impact of strengthening bank capital surveillance on bank heterogeneity in lending, capital accumulation, charter value, and default decisions. To this end, we employ the traditional analytical framework of the incomplete and complete enforcement of regulations, by modeling the degree of efforts of financial agency to inspect and detect whether banks violate the regulator capital requirement, as the probability of inspection on bank capital ratio. In a dynamic model of banks facing idiosyncratic credit quality shocks, highly leveraged and/or profitable banks, in the short run, are more likely to respond to the strengthening of capital surveillance. They decrease charter value (i.e., market value of capital) and lending more than less leveraged and/or less profitable banks, while the overall banks accumulate regulatory capital and decrease charter value and lending on average. By contrast, in the long run, the gradual accumulation of regulatory capital leads to the stability of the banking system.

To test the short-run implications of our model, as a quasi-natural experiment, we utilize the introduction of the prompt corrective action (PCA) program in Japan, which went into preliminary implementation in FY 1997-took full effect in April 1998 - and requested banks to self-assess their assets rigorously. Using some empirical models with bank- and loan-level data, we find that the PCA decreased the lending and charter value of highly leveraged and/or profitable banks more substantially than other banks, albeit increasing the regulatory capital and decreasing the loan supply of the overall banks on average. This empirical result is consistent with our theoretical predictions.

Through the above theoretical and empirical analyses, we now confirm the observation of Sarin and Summers (2016) and as Figure 1 shows, in the case of PCA in Japan that from the short-run perspective, stricter capital regulation increases regulatory capital; however, it can decrease banks' franchise value, which may lead to financial instability. Therefore, at least in terms of this short-run consequence, we agree with Sarin and Summers' (2016) criticism, "regulatory measures of capital (after tightening capital regulation) are flawed." However, our dynamic analysis provides an alternative insight into bank behavior and the stability of banking system after the complete enforcement of capital regulation. The resultant short-run coexistence of the increase in regulatory capital and the decrease in banks' franchise value and lending would be followed by the long-run consequence in the 
form of decrease in banks' default risk and a more stable banking system. This insight may have important implications for regulatory policy.

Appendix: Estimation Results for Relation Survival Probability In subsection 3.3, we included the inverse Mills ratio in the bank loan model to control for survival bias. In this Appendix, we present the estimation results of the probit model, which is used to calculate the inverse Mills ratio.

The literature on relationship banking states that the continuation of a bank-firm relationship depends on the characteristics of both. Our probit regression includes oneperiod lags of banks' market leverage ratio $\left(\operatorname{MARCAP}_{i t-1}\right)$, return on assets $\left(\mathrm{BROA}_{i t-1}\right)$, size $\left(\right.$ BSIZE $\left._{i t-1}\right)$, and the number of firms that have lending-borrowing relationships with bank $i\left(\mathrm{NUMBB}_{i t-1}\right)$. Firm characteristics include one-period lags of firms' book leverage ratio $\left(\mathrm{FBLEV}_{j t-1}\right)$, return on assets $\left(\mathrm{FROA}_{j t-1}\right)$, interest coverage ratio $\left(\mathrm{FICR}_{j t-1}\right)$, size $\left(\mathrm{FSIZE}_{j t-1}\right)$, and the number of banks that have relationships with firm $j\left(\mathrm{NUMBF}_{j t-1}\right)$. To control for the firm-level attributes, we also include dummy variables for the industries to which firms belong. In addition to the bank-firm characteristics, our probit regression includes oneperiod lags of bank $i$ 's lending exposure to firm $j$ ( $\left.\operatorname{LEXP}_{i t-1}^{j}\right)$, firm $j$ 's borrowing exposure to bank $i\left(\mathrm{BEXP}_{i t-1}^{j}\right)$, and the duration of the relationship between lender $i$ and borrowing firm $j\left(\right.$ DURAT $\left._{i t-1}^{j}\right)$ as relationship factors. We conduct rolling estimation of the probit model year-by-year to incorporate time-varying effects of each variable. This year-by-year estimation means that we do not need to include time dummies.

Table A-3 shows the estimation results and indicates that higher borrowing and lending exposure and longer duration of relationships are associated with a higher probability of continuation of relationships. Furthermore, firms with higher profitability tend to continue their relationships with lending banks. A lower firm's interest coverage ratio implies a higher probability of continuation of the relationship, which suggests that firms with high dependence on debt funding tend to continue their relationships with banks. Notably, higher bank leverage was associated with a lower probability of the continuation of relationships in the late 1990s. This suggests that in the late 1990s, a credit crunch occurred in terms of relationship termination, as noted by Nakashima and Takahashi (2020). Overall, dependence on debt finance, higher firm profitability, and higher borrowing and lending 
exposure are associated with higher probability of relationship continuation.

\section{REFERENCES}

[1] Abowd, J., F. Kramarz, and D. Margolis, 1999, High Wage Workers and High Wage Firms, Econometrica, 67, 251-334.

[2] Acemoglu,D., D. Autor, and D. Lyle, 2004, Women, War, and Wages: The Effect of Female Labor Supply on the Wage Structure at Midcentury, Journal of Political Economy, 112, $497-551$.

[3] Andrews, M., L. Gill, T. Schank, and R. Upward, 2008, High Wage Workers and Low Wage Firms: Negative Assortative Matching or Limited Mobility Bias? Journal of the Royal Statistical Society, Series A, 171, 673-697.

[4] Aoki, M., Patrick, H., 1994. The Japanese Main Bank System: Its Relevance for Developing and Transforming Economies. Oxford University Press, Oxford.

[5] Atkeson, A., and A. d'Avernas, 2020, Are U.S. Banks Safer? Reading The Fed's New Dashboard, mimeo.

[6] Atkeson, A., A. d'Avernas, A. Eisfeldt, and P. Weill, 2018, Government Guarantees and the Valuation of American Banks, NBER Macroeconomics Annual, 33.

[7] Begenau, J., S. Bigio, J. Majerovitz, and M. Vieyra, 2019, Banks Adjust Slowly: Evidence and Lessons for Modeling, mimeo.

[8] Begley, T., A. Purnanandam, and K. Zheng, 2017, The Strategic Underreporting of Bank Risk, Review of Financial Studies, 30, 3376-3415.

[9] Bernanke, B., and C. Lown, 1991, The Credit Crunch, Brookings Papers on Economic Activity, 2, 205-239.

[10] Bolton, P., and X. Freixas, 2006, Corporate Finance and the Monetary Transmission Mechanism, The Review of Financial Studies, 19, 829-870.

[11] Cooley, T., and V. Quadrini, 2001, Financial Markets and Firm Dynamics, American Economic Review, 91, 1286-1310. 
[12] Corbae, D., and P. D'Erasmo, 2021, Capital Buffers in a Quantitative Model of Banking Industry Dynamics, Econometrica, forthcoming.

[13] De Nicolò, G., A. Gamba, and M. Lucchetta, 2014, Microprudential Regulation in a Dynamic Model of Banking. The Review of Financial Studies, 27, 2097-2138.

[14] Elizalde, A., and R. Repullo, 2007, Economic and Regulatory Capital in Banking: What Is the Difference? International Journal of Central Banking, 3, 87-117.

[15] Estevadeordal, A., and A. Taylor, 2013, Is the Washington Consensus Dead? Growth, Openness, and the Great Liberalization, 1970s-2000s, Review of Economics and Statistics, 95, $1669-1690$.

[16] Flannery, M., 2012, Corporate Finance and Financial Institutions, Annual Review of Financial Economics, 233-253.

[17] Garvie, D., and A. Keeler, 1994, Incomplete Enforcement with Endogenous Regulatory Choice, Journal of Public Economics, 55, 141-162.

[18] Heckman, J., 1979, Sample Selection Bias as a Specification Error, Econometrica, 47, 153161.

[19] Hennessy, C., and T. Whited, 2007, How Costly is External Financing? Evidence from a Structural Estimation, Journal of Finance, 62, 1705-1745.

[20] Hosono, K., and D. Miyakawa, 2014, Business Cycles, Monetary Policy, and Bank Lending: Identifying the Bank Balance Sheet Channel with Firm-Bank Match-Level Loan Data, mimeo.

[21] Hsieh, T., and P. Klenow, 2009, Misallocation and Manufacturing TFP in China and India, The Quarterly Journal of Economics, 124, 1403-1448.

[22] Ito, T., and K. Harada, 2005, Japan Premium and Stock Prices: Two Mirrors of Japanese Banking Crises, International Journal of Finance and Economics, 10, 195-211.

[23] Jiménez, G., S. Ongena, J. Peydró, and J. Saurina, 2012, Credit Supply and Monetary Policy: Identifying the Bank Balance-Sheet Channel with Loan Applications, American Economic Review, 102, 2301-2326. 
[24] Jiménez, G., S. Ongena, J. Peydró, and J. Saurina, 2014, Hazardous Times for Monetary Policy: What Do Twenty-Three Million Bank Loans Say About the Effects of Monetary Policy on Credit Risk-Taking?, Econometrica, 82, 463-506.

[25] Jones, C., 1989, Standard Setting with Incomplete Enforcement Revisited, Journal of Policy Analysis and Management, 8, 72-87.

[26] Jones, D., and K. King, 1995, The Implementation of Prompt Corrective Action: An assessment, Journal of Banking and Finance, 19, 491-510.

[27] Kanaya, A., and D. Woo, 2000, The Japanese Banking Crisis of the 1990's : Sources and Lessons, IMF Working Papers No. 00/7.

[28] Khwaja, A., and A. Mian, 2008, Tracing the Impact of Bank Liquidity Shocks: Evidence from an Emerging Market, American Economic Review, 98, 1413-1442.

[29] Midrigan, V., and D. Xu, 2014, Finance and Misallocation: Evidence from Plant-Level Data, American economic review, 104, 422-458.

[30] Moll, B., 2014, Productivity Losses from Financial Frictions: Can Self-Financing Undo Capital Misallocation?, American Economic Review, 104, 3186-3221.

[31] Nakashima, K., 2016, An Econometric Evaluation of Bank Recapitalization Programs with Bank- and Loan-Level Data, Journal of Banking and Finance, 63, 1-24.

[32] Nakashima, K., M. Shibamoto, and K. Takahashi, 2020, Risk Taking Channel of Unconventional Monetary Policies in Bank Lending, mimeo.

[33] Nakashima, K., and K. Takahashi, 2018, The Real Effects of Bank-Driven Termination of Relationships: Evidence from Loan-Level Matched Data, Journal of Financial Stability, 39, $46-65$.

[34] Nakashima, K., and K. Takahashi, 2020, The Time Has Come for Banks to Say Goodbye: New Evidence on Banks' Roles and Duration Effects in Relationship Terminations, Journal of Banking and Finance, 105813.

[35] Ongena, S., and D. Smith, 2001, The Duration of Bank Relationships, Journal of Financial Economics, 61, 449-475. 
[36] Peek, J., and E. Rosengren, 1995, Bank Regulation and the Credit Crunch, Journal of Banking and Finance, 19, 679-692.

[37] Polinsky, M., and S. Shavell, 1979, The Optimal Tradeoff between the Probability and Magnitude of Fines, American Economic Review, 69, 880-891.

[38] Sarin, N., and L. Summers, 2016, Understanding Bank Risk through Market Measures, Brookings Papers on Economic Activity, 2, 57-109.

[39] Sekino, M., and W. Watanabe, 2014, Does the Policy Lending of the Government Financial Institution Substitute the Private Lending during the Period of the Credit Crunch? Evidence from the Loan Level Data in Japan, mimeo.

[40] Shleifer, A., 2005, Understanding Regulation, European Financial Management, 4, 439-451.

[41] Shrieves, R., and D. Dahl, 2003, Discretionary Accounting and the Behavior of Japanese Banks under Financial Duress, Journal of Banking and Finance, 27, 1219-1243.

[42] Skinner, D., 2008, The Rise of Deferred Tax Assets in Japan: The Case of the Major Japanese Banks, Journal of Accounting and Economics, 46, 218-239.

[43] Stigler, G., 1970, The Optimum Enforcement of Laws, Journal of Political Economy, 78, $526-536$.

[44] Tauchen, G., 1986, Finite State Markov-chain Approximations to Univariate and Vector Autoregressions, Economics letters, 20, 177-181.

[45] Watanabe, W., 2007, Prudential Regulation and the Credit Crunch: Evidence from Japan, Journal of Money, Credit and Banking, 39, 639-665.

[46] Woo, D., 2003, In Search of "Capital Crunch": Supply Factors behind the Credit Slowdown in Japan, Journal of Money, Credit and Banking, 35, 1019-1038. 
Table 1: Model Parameters

\begin{tabular}{c|c|c|c}
\hline \hline Parameter & & Value & Target (Source) \\
\hline Deposit Rate & $R^{d}$ & 0 & DeNicolo et al. (2014) \\
Discount Factor of Bankers & $\beta$ & 0.95 & Cost of Bank Capital 5\% (DeNicolo et al. (2014)) \\
Revenue Function of Loans & $f(x)$ & $x^{0.9}$ & DeNicolo et al. (2014) \\
Capital Requirement & $\phi$ & 0.08 & Basel Accords \\
\hline Persistency of i.d. Shock & $\rho$ & 0.76 & Panel Data on ROA (FYs 1975-1996) \\
Std. Dev. of i.d. Shock & $\sigma$ & 0.15 & Panel data on ROA (FYs 1975-1996) \\
Mean of i.d. Shock & $\log z$ & 0.27 & Panel Data on ROA (FYs 1975-1996) \\
\hline Fixed Cost & $k$ & 1.05 & Annual Bank's Default Rate 1\% \\
Equity Issuance Cost & $a$ & 0.33 & Capital Surplus after PCA 4\% \\
Inspection Prob. before PCA & $p_{0}$ & 0.25 & Capital Surplus before PCA 1\% \\
Inspection Prob. after PCA & $p_{1}$ & 1 & Assumption (complete enforcement) \\
\hline \hline
\end{tabular}

Notes: This table reports the parameter values for our calibration. The middle panel shows estimation results for equation (17) introduced in subsection 2.3.1.

Table 2: Summary of Capital Surplus (Capital Ratio minus the Required Level)

\begin{tabular}{c|c|c}
\hline \hline Fiscal Year & Mean (\%) & Number of Banks \\
\hline 1994 & .91079137 & 139 \\
\hline 1995 & 1.1691304 & 138 \\
\hline 1996 & .97183823 & 136 \\
\hline 1997 & 3.142406 & 133 \\
\hline 1998 & 3.391 & 130 \\
\hline 1999 & 4.4944776 & 134 \\
\hline 2000 & 4.0996297 & 135 \\
\hline \hline
\end{tabular}

Notes: This table reports the sample average of the regulatory capital buffer calculated in each fiscal year.

Table 3: Model and Target Moments

\begin{tabular}{c|c|c}
\hline \hline Moment & Target & Model \\
\hline Default Rate of Banks (\%) & 1 & 0.98 \\
Capital Surplus after PCA (\%) & 4 & 3.99 \\
Capital Surplus before PCA (\%) & 1 & 1.38 \\
\hline \hline
\end{tabular}

Notes: This table reports the targeted values of the default rate, and those of the capital surplus before and after the preliminary implementation of Japan's prompt corrective action (PCA) program in FY 1997. 
Table 4: Estimated Impacts of the PCA on Regulatory Capital, Market Capital Ratio, and Bank Lending

\begin{tabular}{|c|c|c|c|c|c|c|c|c|c|c|c|c|c|c|c|}
\hline \multirow{4}{*}{$\begin{array}{l}\text { Outcome Variable } \\
\text { BUFFER }_{i t-1}\end{array}$} & \multicolumn{6}{|c|}{ Regulatory Capital Ratio } & \multirow{2}{*}{\multicolumn{3}{|c|}{ Market Capital Ratio }} & \multicolumn{6}{|c|}{ Bank Lending } \\
\hline & \multicolumn{3}{|c|}{ Level } & \multicolumn{3}{|c|}{ Buffer } & & & & \multicolumn{3}{|c|}{ Bank Level } & \multicolumn{3}{|c|}{ Loan Level } \\
\hline & 0.221 & & 0.257 & 0.109 & & 0.121 & 0.262 & & 0.240 & -0.872 & & -0.855 & -0.909 & & -0.922 \\
\hline & $(0.149)$ & & $(0.188)$ & $(0.300)$ & & $(0.328)$ & $(0.186)$ & & $(0.165)$ & $(0.626)$ & & $(0.625)$ & $(0.614)$ & & $(0.617)$ \\
\hline \multirow[t]{2}{*}{$\mathrm{ROA}_{i t-1}$} & & $-0.510^{*}$ & -0.600 & & $-0.372^{* *}$ & -0.291 & & $0.175^{* *}$ & 0.227 & & $0.262^{*}$ & -0.651 & & $0.230^{* * *}$ & -0.325 \\
\hline & & $(0.253)$ & $(0.529)$ & & $(0.177)$ & $(0.993)$ & & $(0.079)$ & $(0.381)$ & & $(0.131)$ & $(1.632)$ & & $(0.077)$ & $(1.262)$ \\
\hline \multirow[t]{2}{*}{$\mathrm{BUFFER}_{i t-1} * \mathrm{ROA}_{i t-1}$} & & & 0.491 & & & 0.123 & & & -0.342 & & & $-2.529^{* *}$ & & & $-3.492^{* * *}$ \\
\hline & & & $(0.446)$ & & & $(0.289)$ & & & $(0.289)$ & & & $(1.110)$ & & & $(0.819)$ \\
\hline \multirow[t]{2}{*}{$t_{1997}$} & $1.362^{* * *}$ & $1.156^{* * *}$ & $1.256^{* * *}$ & $2.720^{* * *}$ & $2.489^{* * *}$ & $2.644^{* * *}$ & $-0.562 * * *$ & $-0.496^{* * *}$ & $-0.452^{* * *}$ & $-0.589^{* *}$ & $-0.498^{*}$ & $-0.503^{* *}$ & & & \\
\hline & $(0.391)$ & $(0.200)$ & $(0.190)$ & $(0.329)$ & $(0.307)$ & $(0.335)$ & $(0.299)$ & $(0.212)$ & $(0.149)$ & $(0.272)$ & $(0.241)$ & $(0.232)$ & & & \\
\hline \multirow[t]{2}{*}{ BUFFER $_{i t-1} * t_{1997}$} & $-0.201 *$ & & $-0.301 * * *$ & -0.527 & & $-0.455^{* *}$ & $0.299^{* *}$ & & $0.259^{* * *}$ & $0.692^{* *}$ & & $0.664^{*}$ & $0.782^{* *}$ & & $0.810^{* *}$ \\
\hline & $(0.119)$ & & $(0.119)$ & $(0.290)$ & & $(0.210)$ & $(0.132)$ & & $(0.089)$ & $(0.332)$ & & $(0.335)$ & $(0.372)$ & & $(0.385)$ \\
\hline \multirow[t]{2}{*}{$\mathrm{ROA}_{i t-1} * t_{1997}$} & & $0.723^{*}$ & $0.618^{* *}$ & & $0.341^{* *}$ & $0.280^{*}$ & & $-0.821^{*}$ & $-0.719^{* *}$ & & -2.059 & $-3.149^{*}$ & & $-3.467^{* * *}$ & $-3.354^{* * *}$ \\
\hline & & $(0.361)$ & $(0.281)$ & & $(0.152)$ & $(0.147)$ & & $(0.417)$ & $(0.296)$ & & $(1.885)$ & $(1.685)$ & & $(1.273)$ & $(1.012)$ \\
\hline \multirow[t]{2}{*}{ BUFFER $_{i t-1} * \mathrm{ROA}_{i t-1} * t_{1997}$} & & & $-0.386^{*}$ & & & $-0.670^{* *}$ & & & $0.554^{*}$ & & & $2.820^{* * *}$ & & & $3.231^{* * *}$ \\
\hline & & & $(0.196)$ & & & $(0.298)$ & & & $(0.287)$ & & & $(1.019)$ & & & $(0.681)$ \\
\hline \multirow[t]{2}{*}{ Inverse Mills Ratio ${ }_{i t}^{j}$} & & & & & & & & & & & & & $-0.809^{* * *}$ & $-0.757^{* * *}$ & $-0.834^{* * *}$ \\
\hline & & & & & & & & & & & & & $(0.154)$ & $(0.189)$ & $(0.122)$ \\
\hline \multirow[t]{2}{*}{ Constant } & -52.81 & -47.62 & -50.92 & -80.15 & -86.72 & -82.21 & -38.41 & -40.43 & -41.84 & $-359.1^{* * *}$ & $-381.8^{* * *}$ & $-377.8^{* * * *}$ & $-220.4^{* *}$ & -197.4 & $-221.4^{*}$ \\
\hline & $(58.82)$ & $(50.07)$ & $(54.52)$ & $(92.38)$ & $(98.11)$ & $(96.82)$ & $(39.98)$ & $(40.09)$ & $(41.33)$ & $(151.1)$ & $(172.5)$ & $(167.7)$ & $(100.9)$ & $(132.9)$ & $(111.5)$ \\
\hline Bank Fix. Eff. & yes & yes & yes & yes & yes & yes & yes & yes & yes & yes & yes & yes & yes & yes & yes \\
\hline Firm-Year Fix. Eff. & & & & & & & & & & & & & yes & yes & yes \\
\hline Obs. & 232 & 232 & 232 & 232 & 232 & 232 & 232 & 232 & 232 & 232 & 232 & 232 & 42907 & 42907 & 42907 \\
\hline
\end{tabular}

Notes: This table shows the results of regressions (18) and (19) to examine the impacts of the preliminary implementation of the prompt corrective action (PCA) program in FY 1997 on the regulatory capital, market capital ratio, and bank lending. ***, **, * indicate $1 \%, 5 \%$, and $10 \%$ levels of significance, respectively. Robust standard errors are in parentheses. Estimated coefficients on bank control variables $\left(\right.$ CONTROLS $\left._{i t-1}\right)$ and two relationship variables $\left(\right.$ LEXP $_{i t-1}^{j}$ and $\left.\mathrm{BEXP}_{i t-1}^{j}\right)$ are not reported. 
Table 5: Placebo Test for FYs 1994, 1995 and 1996

\begin{tabular}{lcccc}
\hline \hline \multirow{2}{*}{ Fiscal Year 1994 } & Buffer & Market Cap. Ratio & \multicolumn{2}{c}{ Lending } \\
& & & Bank Level & Loan Level \\
\hline$t_{\mathrm{FY} 1994}$ & 0.026 & 0.023 & -0.210 & \\
& $(0.081)$ & $(0.092)$ & $(0.225)$ & \\
BUFFER $_{i t-1} * t_{1994}$ & 0.121 & -0.461 & 0.421 & 0.515 \\
& $(0.101)$ & $(0.312)$ & $(0.411)$ & $(0.504)$ \\
ROA $_{i t-1} * t_{1994}$ & 0.597 & $0.672^{*}$ & -1.827 & 3.289 \\
& $(0.640)$ & $(0.339)$ & $(1.871)$ & $(3.227)$ \\
BUFFER $_{i t-1} * \mathrm{ROA}_{i t-1} * t_{1994}$ & 0.242 & -0.576 & 1.262 & 2.844 \\
& $(0.284)$ & $(0.917)$ & $(1.072)$ & $(2.699)$ \\
\hline obs. & 252 & 252 & 252 & 42959 \\
\hline \hline
\end{tabular}

\begin{tabular}{lcccc}
\hline \hline \multirow{2}{*}{ Fiscal Year 1995 } & Buffer & Market Cap. Ratio & \multicolumn{2}{c}{ Lending } \\
& & & Bank Level & Loan Level \\
\hline$t_{\mathrm{FY} 1995}$ & 0.226 & -0.144 & -0.131 & \\
& $(0.251)$ & $(0.099)$ & $(0.288)$ & \\
BUFFER $_{i t-1} * t_{1995}$ & & & & \\
& $0.121^{*}$ & -0.211 & 0.513 & 0.812 \\
& $(0.064)$ & $(0.224)$ & $(0.420)$ & $(0.859)$ \\
ROA $_{i t-1} * t_{1995}$ & -0.220 & 0.692 & -3.184 & -3.365 \\
& $(0.351)$ & $(0.900)$ & $(2.988)$ & $(3.212)$ \\
BUFFER $_{i t-1} * \mathrm{ROA}_{i t-1} * t_{1995}$ & 0.322 & 0.892 & & \\
& $(0.224)$ & $(1.201)$ & $(1.722)$ & $(1.892)$ \\
\hline obs. & 248 & 248 & 248 & 46843 \\
\hline \hline
\end{tabular}

\begin{tabular}{lcccc}
\hline \hline \multirow{2}{*}{ Fiscal Year 1996 } & Buffer & Market Cap. Ratio & \multicolumn{2}{c}{ Lending } \\
& & & Bank Level & Loan Level \\
\hline$t_{\mathrm{FY} 1996}$ & 0.218 & $-0.592^{* * *}$ & -0.112 & \\
& $(0.274)$ & $(0.188)$ & $(0.229)$ & \\
BUFFER $_{i t-1} * t_{1996}$ & 0.114 & 0.250 & 0.225 & 0.219 \\
& $(0.098)$ & $(0.237)$ & $(0.394)$ & $(0.283)$ \\
$\mathrm{ROA}_{i t-1} * t_{1996}$ & 0.329 & 0.749 & -2.358 & -3.436 \\
& $(0.351)$ & $(1.291)$ & $(2.890)$ & $(3.642)$ \\
$\mathrm{BUFFER}_{i t-1} * \mathrm{ROA}_{i t-1} * t_{1996}$ & 0.241 & 0.484 & & \\
& $(0.274)$ & $(0.814)$ & $(2.690)$ & $(2.872)$ \\
\hline obs. & 238 & 238 & 238 & 47832 \\
\hline \hline
\end{tabular}

Notes: This table shows only estimated coefficients of the time dummies of FYs 1994-1996 and their interaction terms with banks' capital buffer and ROA for regressions (18) and (19), obtained using sample periods before the prompt corrective action (PCA) program in FY 1997. ***, **, * indicate $1 \%, 5 \%$, and $10 \%$ levels of significance, respectively. Robust standard errors are in parentheses. 
Table A-1: Summary Statistics for Bank-level Data: Fiscal Years 1996 - 1997

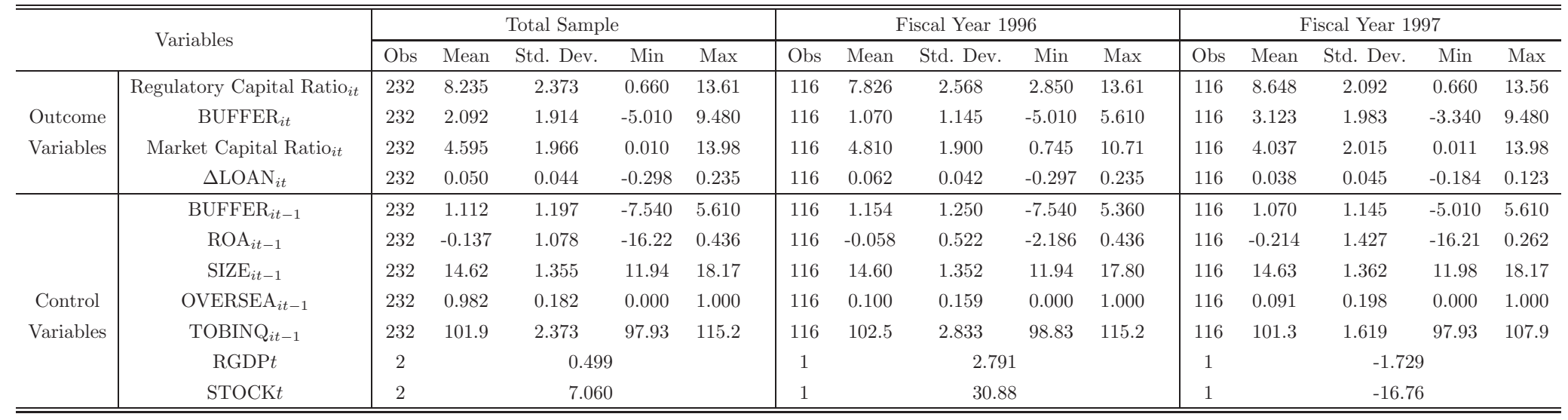

Notes: See subsection 3.2 for the definition of each variable. The annual growth rate of real GDP (RGDP $t$ ) is defined as percent change in the first quarter. The annual return of the TOPIX index (STOCKt) is calculated using closing values at the last trading day in March.

Table A-2: Summary Statistics for Loan-level Data: Fiscal Years 1996 - 1997

\begin{tabular}{|c|c|c|c|c|c|c|c|c|c|c|c|c|c|c|c|c|}
\hline \multirow{2}{*}{\multicolumn{2}{|c|}{ Variables }} & \multicolumn{5}{|c|}{ Total Sample } & \multicolumn{5}{|c|}{ Fiscal Year 1996} & \multicolumn{5}{|c|}{ Fiscal Year 1997} \\
\hline & & \multirow{2}{*}{$\begin{array}{c}\text { Obs } \\
42907\end{array}$} & \multirow{2}{*}{$\begin{array}{l}\text { Mean } \\
0.178\end{array}$} & \multirow{2}{*}{$\begin{array}{c}\text { Std. Dev. } \\
2.252\end{array}$} & \multirow{2}{*}{$\begin{array}{c}\text { Min } \\
-0.999\end{array}$} & \multirow{2}{*}{$\begin{array}{l}\text { Max } \\
276.2\end{array}$} & \multirow{2}{*}{$\begin{array}{l}\text { Obs } \\
21453\end{array}$} & \multirow{2}{*}{$\begin{array}{l}\text { Mean } \\
0.209\end{array}$} & \multirow{2}{*}{$\begin{array}{c}\text { Std. Dev. } \\
1.987\end{array}$} & \multirow{2}{*}{$\begin{array}{c}\text { Min } \\
-0.999\end{array}$} & \multirow{2}{*}{$\begin{array}{c}\operatorname{Max} \\
100\end{array}$} & \multirow{2}{*}{$\begin{array}{c}\text { Obs } \\
21454\end{array}$} & \multirow{2}{*}{$\begin{array}{l}\text { Mean } \\
0.147\end{array}$} & \multirow{2}{*}{$\begin{array}{c}\text { Std. Dev. } \\
2.498\end{array}$} & \multirow{2}{*}{$\begin{array}{c}\text { Min } \\
-0.996\end{array}$} & \multirow{2}{*}{$\begin{array}{l}\text { Max } \\
276.2\end{array}$} \\
\hline Dependent Variable & $\Delta \mathrm{LOAN}_{i t}^{j}$ & & & & & & & & & & & & & & & \\
\hline \multirow{5}{*}{ Factor of bank $i$} & BUFFER $_{i t-1}$ & 42907 & 1.224 & 1.012 & -7.540 & 5.610 & 21453 & 1.299 & 0.908 & -7.540 & 5.360 & 21454 & 1.152 & 1.097 & -5.010 & 5.610 \\
\hline & $\mathrm{ROA}_{i t-1}$ & 42907 & -0.178 & 0.529 & -16.21 & 0.649 & 21453 & -0.343 & 0.613 & -16.21 & 0.649 & 21454 & -0.020 & 0.368 & -2.186 & 0.436 \\
\hline & $\mathrm{SIZE}_{i t-1}$ & 42907 & 16.71 & 1.275 & 11.53 & 18.17 & 21453 & 16.67 & 1.259 & 11.53 & 17.95 & 21454 & 16.75 & 1.289 & 11.98 & 18.17 \\
\hline & OVERSEA $_{i t-1}$ & 42907 & 0.173 & 0.136 & 0.000 & 1.000 & 21453 & 0.178 & 0.132 & 0.000 & 1.000 & 21454 & 0.169 & 1.40 & 0.000 & 1.000 \\
\hline & TOBINQ $_{i t-1}$ & 42907 & 104.0 & 3.355 & 97.93 & 123.8 & 21453 & 105.3 & 3.827 & 98.76 & 123.8 & 21454 & 102.8 & 2.230 & 97.93 & 123.8 \\
\hline Relationship Factor & 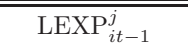 & 42907 & (0.600 & 2.660 & "0.000 & 100.0 & 21453 & 0.623 & 2.724 & (0.000 & 92.30 & 21454 & 0.578 & 2.596 & "0.000 & 100.0 \\
\hline of lender $i$ and borrower $j$ & $\operatorname{BEXP}_{i t-1}^{j}$ & 42907 & 10.12 & 12.80 & 0.002 & 100.0 & 21453 & 9.698 & 12.37 & 0.002 & 100.0 & 21454 & 10.51 & 13.17 & 0.003 & 100.0 \\
\hline
\end{tabular}

Notes: See subsection 3.2 for the definition of each variable. 


\section{Table A-3: Results for the Survivorship Model of Bank-Firm Relationships}

\begin{tabular}{|c|c|c|}
\hline Fiscal Year & 1996 & 1997 \\
\hline $\operatorname{MARCAP}_{i t-1}$ & $\begin{array}{c}-0.059^{* * *} \\
(-6.03)\end{array}$ & $\begin{array}{l}-0.022^{*} \\
(-1.69)\end{array}$ \\
\hline BSIZE $_{i t-1}$ & $\begin{array}{c}0.212^{* * *} \\
(5.16)\end{array}$ & $\begin{array}{c}0.100^{* *} \\
(2.17)\end{array}$ \\
\hline $\mathrm{BROA}_{i t-1}$ & $\begin{array}{c}0.128^{* * *} \\
(4.97)\end{array}$ & $\begin{array}{c}0.054^{* *} \\
(2.54)\end{array}$ \\
\hline $\mathrm{FLEV}_{t-1}^{j}$ & $\begin{array}{c}0.015^{* * *} \\
(5.97)\end{array}$ & $\begin{array}{l}0.0006 \\
(0.24)\end{array}$ \\
\hline $\operatorname{FSIZE}_{t-1}^{j}$ & $\begin{array}{l}0.106 \\
(1.31)\end{array}$ & $\begin{array}{c}0.364^{* * *} \\
(3.91)\end{array}$ \\
\hline $\mathrm{FROA}_{t-1}^{j}$ & $\begin{array}{c}0.009^{* * *} \\
(3.34)\end{array}$ & $\begin{array}{c}0.00101 \\
(0.62)\end{array}$ \\
\hline $\mathrm{FICR}_{t-1}^{j}$ & $\begin{array}{c}0.00000177^{* *} \\
(2.34)\end{array}$ & $\begin{array}{c}-0.000000292 \\
(-0.22)\end{array}$ \\
\hline DURAT & $\begin{array}{c}0.013^{* * *} \\
(7.79)\end{array}$ & $\begin{array}{c}0.010^{* * *} \\
(6.20)\end{array}$ \\
\hline $\operatorname{EXPL}_{i t-1}^{j}$ & $\begin{array}{l}0.0002 \\
(0.05)\end{array}$ & $\begin{array}{c}0.073^{* * *} \\
(6.44)\end{array}$ \\
\hline $\mathrm{EXPB}_{i t-1}^{j}$ & $\begin{array}{c}0.014^{* * *} \\
(12.92)\end{array}$ & $\begin{array}{c}0.008^{* * *} \\
(8.71)\end{array}$ \\
\hline $\operatorname{NUMBL}_{i t-1}$ & $\begin{array}{c}0.299^{* * *} \\
(9.54)\end{array}$ & $\begin{array}{c}0.231^{* * *} \\
(7.43)\end{array}$ \\
\hline $\operatorname{NUMBB}_{t-1}^{j}$ & $\begin{array}{c}-0.187^{* * *} \\
(-4.35)\end{array}$ & $\begin{array}{c}-0.00246 \\
(-0.05) \\
\end{array}$ \\
\hline$N$ & 21453 & 21454 \\
\hline
\end{tabular}

Notes: This table shows the estimation results of the model with industry fixed effects. The dependent variable is the survival dummy variable, which equals one if the borrower-lender relationship continues in year $t$ and zero otherwise. See also the Appendix for details on our variable definition. We also include five-year moving average values of the firm ROA, interest coverage ratio, book leverage ratio, and size to control for time-varying firm fixed effects. The table does not show the estimated coefficients. *, **, and *** denote significance at levels of $0.10,0.05$, and 0.01 , respectively. $t$ statistics are in parentheses. 


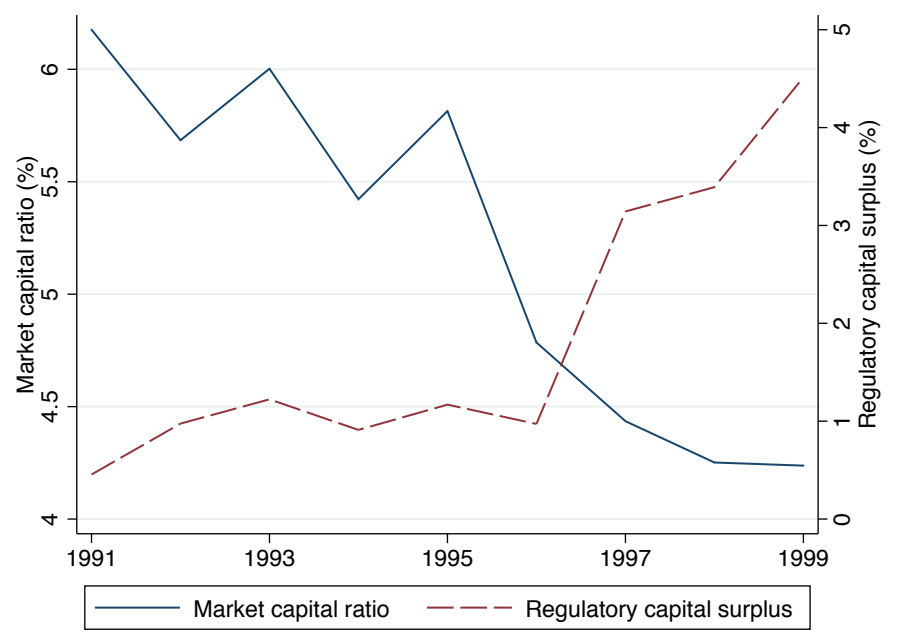

Figure 1: Bank Market Capital Ratio and Regulatory Capital Surplus

Notes: The solid line shows the sample mean of the market capital ratio calculated as of the end of March in each year and the dashed line shows the sample mean of the regulatory capital surplus. The bank market capital ratio is defined as the market value of a bank's equity divided by the market value of its total assets, where the market value of a bank's total assets is defined as the sum of the market value of its equity and the book value of its total liabilities. The regulatory capital surplus is defined as the difference between a bank's reported regulatory capital ratio and its regulatory target ratio $(8 \%$ for international banks and $4 \%$ for domestic banks). 


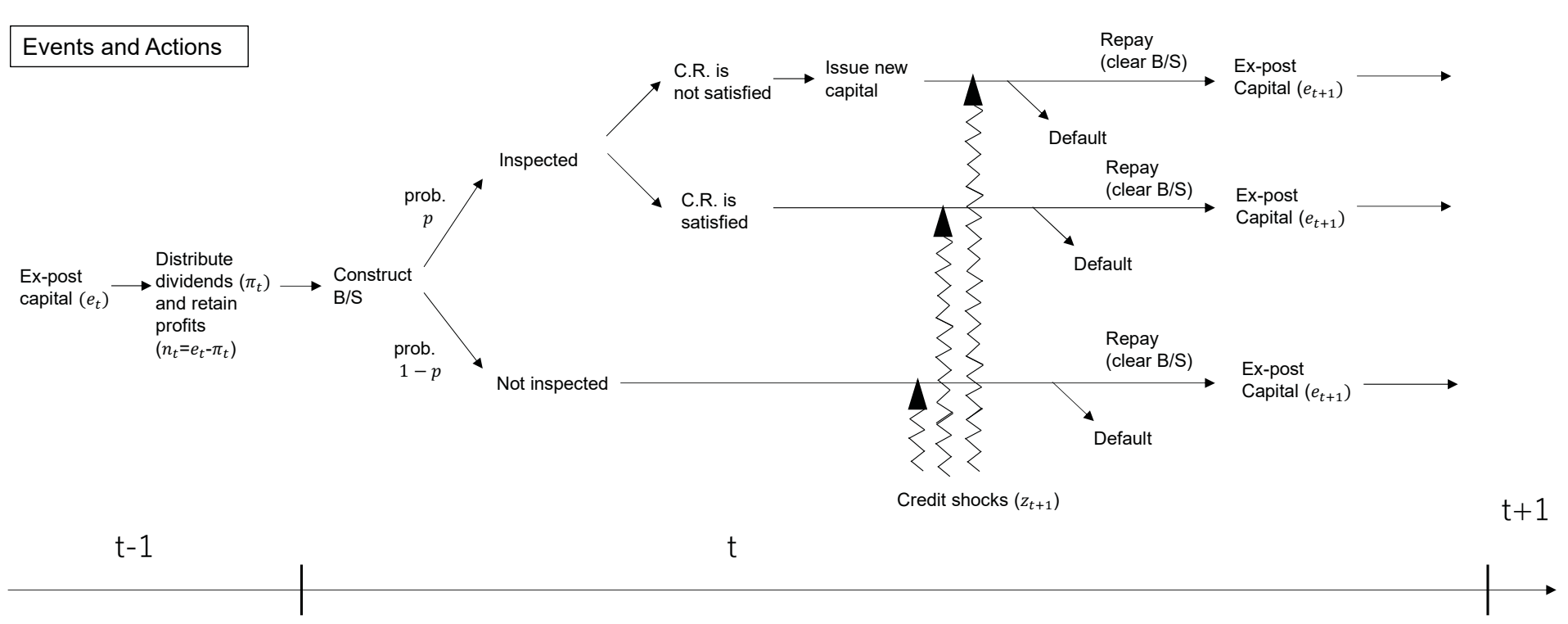

Balance sheet (B/S)

If the bank is inspected and C.R. is not Credit shocks occur to assets

\begin{tabular}{|c|c|}
\hline Loans & $\begin{array}{c}\text { Deposits } \\
d_{t}\end{array}$ \\
\hline$l_{t}$ & $n_{t}$ \\
\hline
\end{tabular}

atisfied, it needs to is
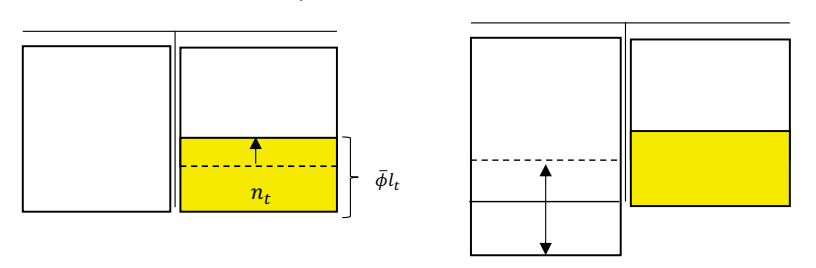


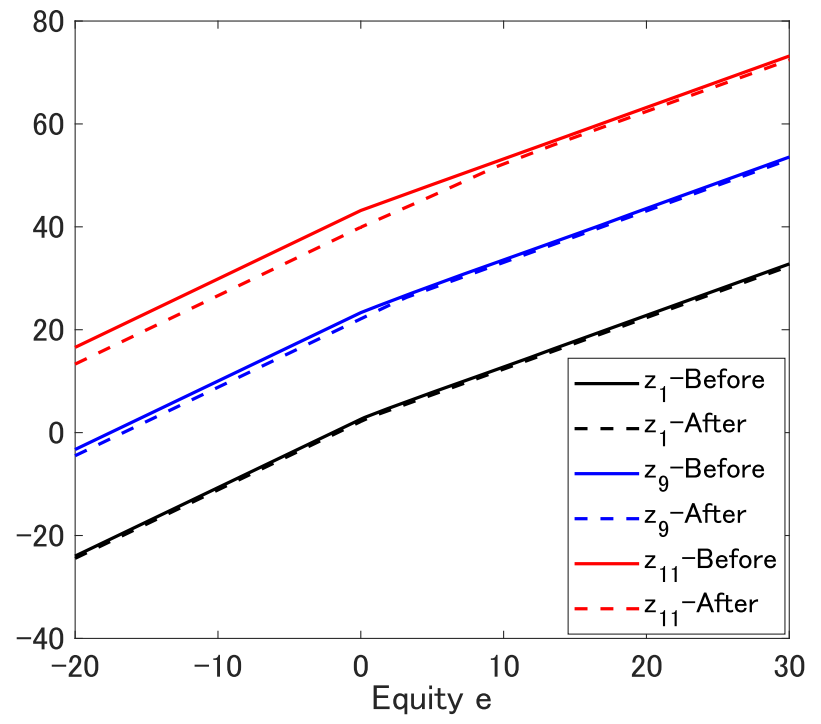

Figure 3: Value Functions

Notes: Solid lines with before and dashed lines with after show the bank values generated at the inspection probability of $p_{0}=0.25$ and $p_{1}=1$ (i.e., before and after the strengthening of surveillance pressure), respectively. To solve the bank problem, credit shocks $z_{t}$ that each bank faces are discretized into 11 states $\left(z_{1}, z_{2}, \ldots, z_{11}\right)$. $z_{1}$ is the worst credit shock, $z_{9}$ is the better credit shock, and $z_{11}$ is the best credit shock. We report bank values for the worst, better, and best credit shocks.

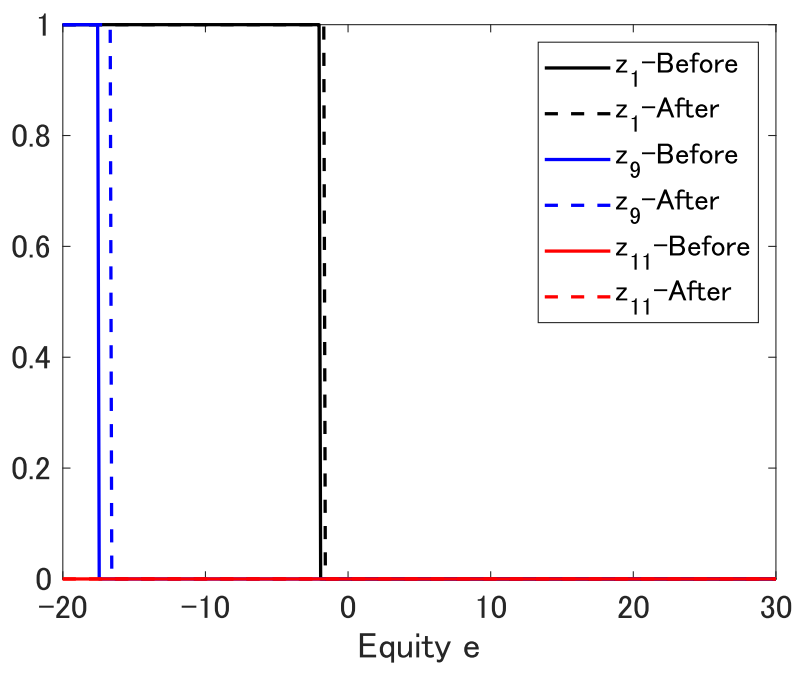

Figure 4: Default Decisions

Notes: See Notes in Figure 3. We report default rates for the worst $\left(z_{1}\right)$, better $\left(z_{9}\right)$, and best credit shocks $\left(z_{11}\right)$. 


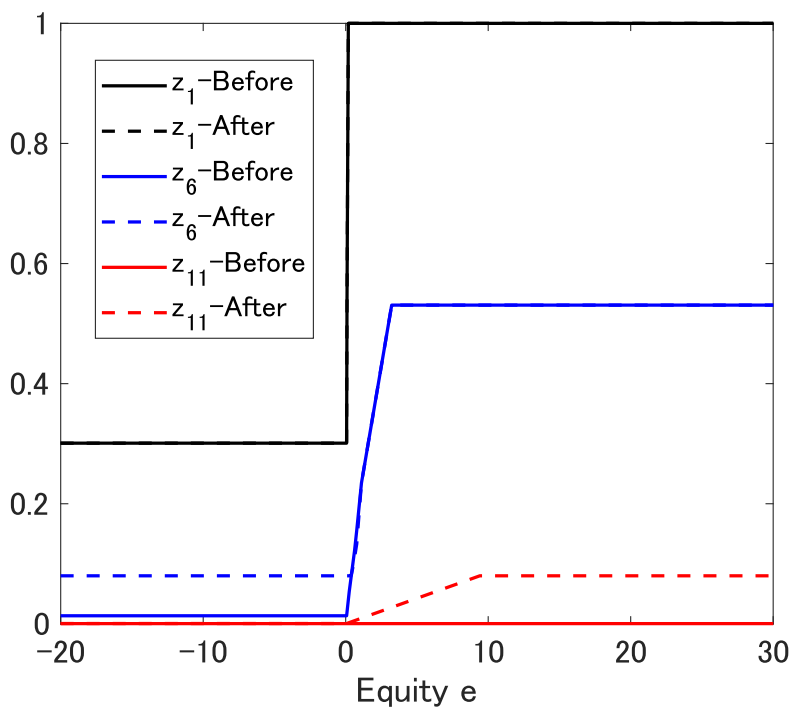

Figure 5: Capital Ratio Decisions

Notes: See Notes in Figure 3. We report bank capital ratios for the cases of the worst $\left(z_{1}\right)$, average $\left(z_{6}\right)$, and best credit shocks $\left(z_{11}\right)$.

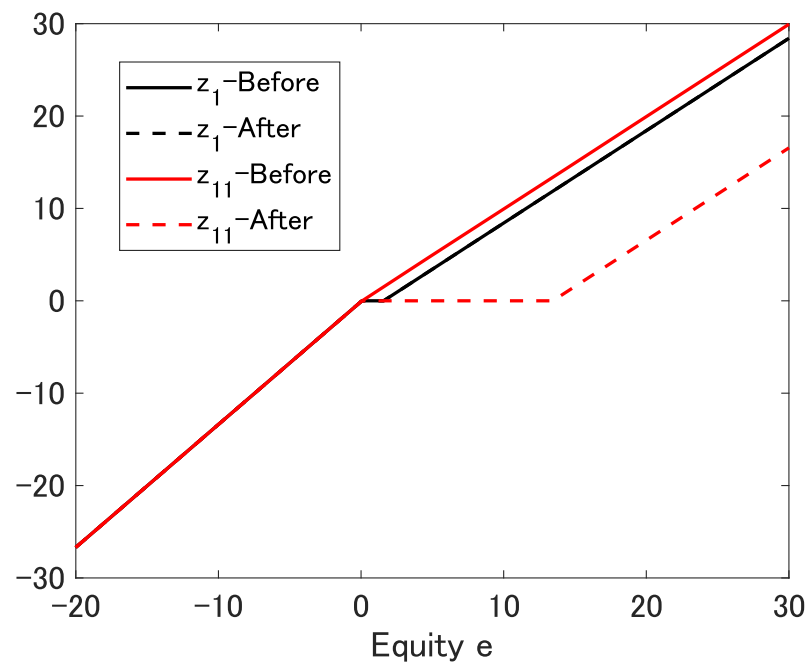

Figure 6: Dividend Decisions

Notes: See Notes in Figure 3. We report dividend by banks for the worst $\left(z_{1}\right)$ and best credit shocks $\left(z_{11}\right)$. 


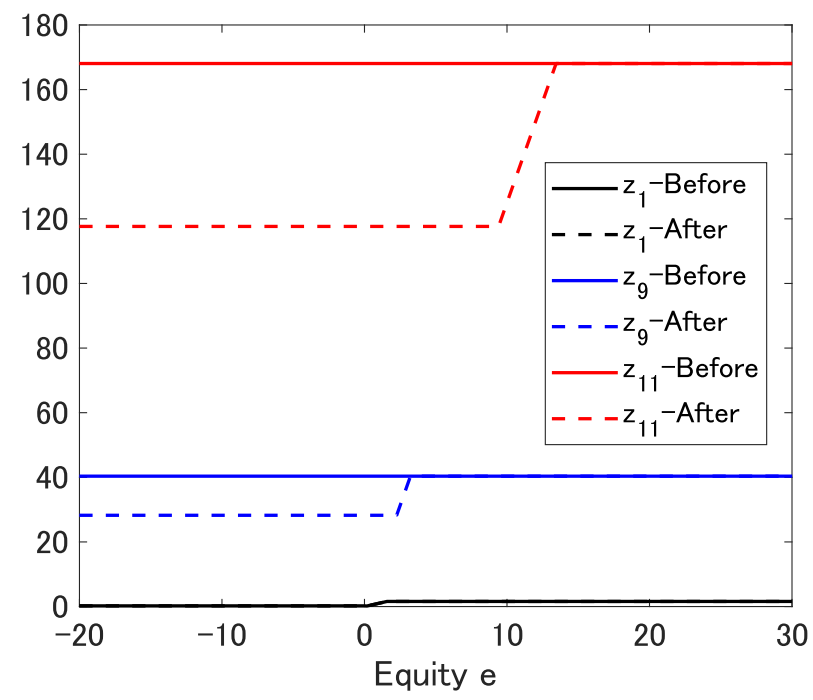

Figure 7: Loan Decisions

Notes: See Notes in Figure 3. We report bank loan supply for the worst $\left(z_{1}\right)$, better $\left(z_{9}\right)$, and best credit shocks $\left(z_{11}\right)$.

Figure 8: Stationary Distribution of Capital Ratio

Before Strengthening Capital

Surveillance $\left(p=p_{0}(=0.25)\right)$

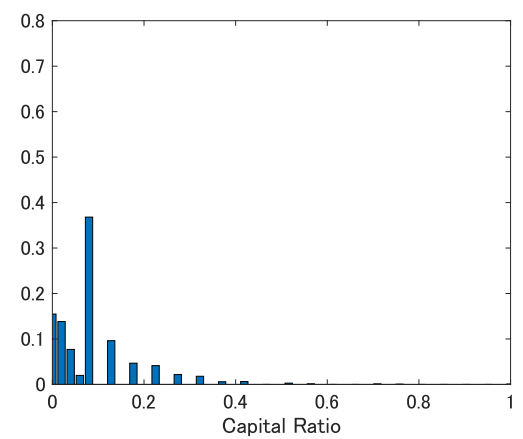

After Strengthening Capital

Surveillance $\left(p=p_{1}(=1)\right)$

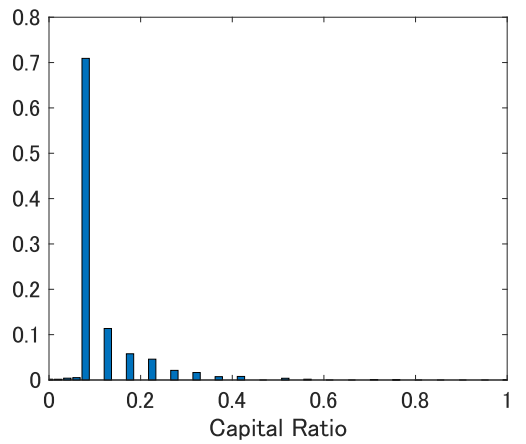

Notes: Left and right panels show the stationary distributions of bank capital ratio generated at the inspection probability of $p_{0}=0.25$ and $p_{1}=1$ (i.e., before and after strengthening capital surveillance), respectively. 
Figure 9: Impulse Responses to Strengthening Capital Surveillance

(a) Average of Regulatory Capital Ratio (\%)

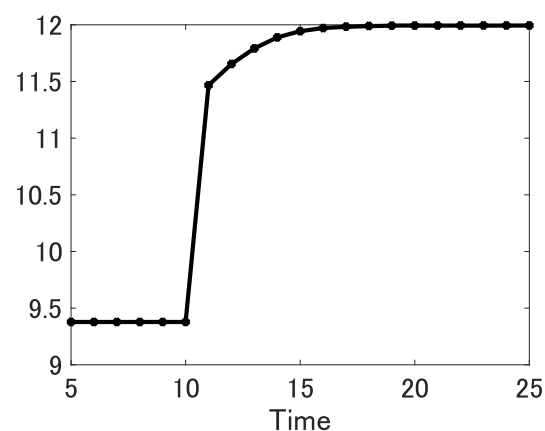

(c) Average of Market Capital Ratio

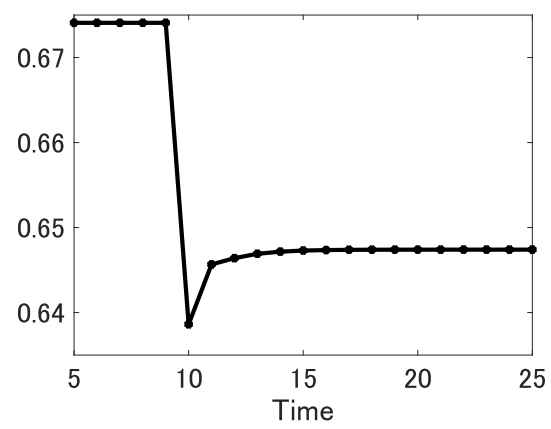

(b) Total Amount of Dividends

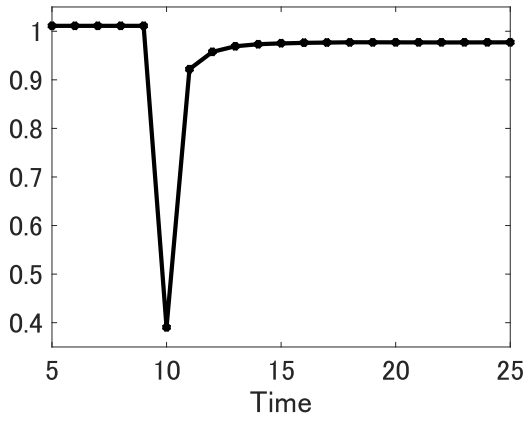

(d) Bank Default Rate

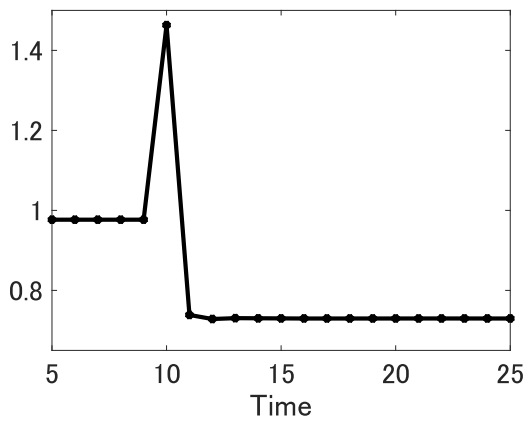

(e) Total Amount of Loans

(Deviation (\%))

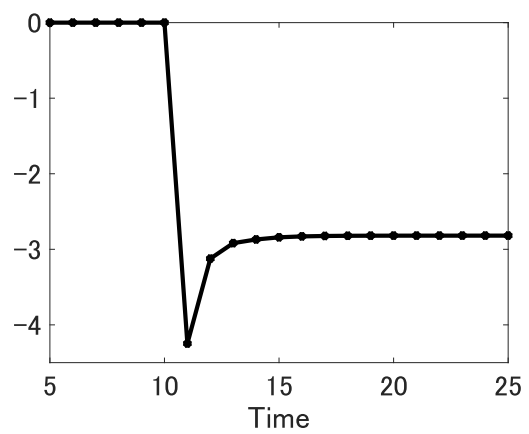

Notes: The solid lines indicate that the impulse responses of the aggregate bank variables to the increase in the inspection probability from $p_{0}=0.25$ to $p_{1}=1$. We assume the economy is, initially, at the stationary equilibrium of $p=p_{0}$ and the inspection probability increases to $p=p_{1}$, unexpectedly, at $t=10$, that is, the announcement about the transition from incomplete enforcement of capital regulation to complete enforcement occurs before banks' default decisions at $t=10$. If a bank defaults, it is replaced with a new bank with zero equity capital; hence, the number of banks does not change over time. The economy transits from the initial stationary equilibrium $\left(p=p_{0}\right)$ to the next one $\left(p=p_{1}\right)$. 